\title{
Imogolite Nanotubes: A Flexible Nanoplatform with Multipurpose Applications
}

\author{
Erwan Paineau ${ }^{\mathbb{D}}$
}

Laboratoire de Physique des Solides, UMR CNRS 8502, Univ. Paris Sud, Université Paris Saclay, 91405 Orsay CEDEX, France; erwan-nicolas.paineau@u-psud.fr; Tel.: +33-1-69156051

Received: 25 September 2018; Accepted: 11 October 2018; Published: 15 October 2018

\begin{abstract}
Among a wide variety of inorganic nanotubes, imogolite nanotubes (INTs) represent a model of nanoplatforms with an untapped potential for advanced technological applications. Easily synthesized by sol-gel methods, these nanotubes are directly obtained with a monodisperse pore size. Coupled with the possibility to adjust their surface properties by using straightforward functionalization processes, INTs form a unique class of diameter-controlled nanotubes with functional interfaces. The purpose of this review is to provide the reader with an overview of the synthesis and functionalization of INTs. The properties of INTs will be stated afterwards into perspective with the recent development on their applications, in particular for polymer/INTs nanocomposites, molecular confinement or catalysis.
\end{abstract}

Keywords: imogolite; nanotube; synthesis; functionalization; nanocomposite; hydrogels; molecular sieving; liquid crystals; catalysis

\section{Introduction}

Hollow cylinders with a diameter ranging between 1 and $100 \mathrm{~nm}$, so-called nanotubes, are carving out prime positions in nanoscience and nanotechnology. Research into these systems started with Iijima's 1991 seminal article on multi-walled carbon nanotubes (MWCNT) [1]. This was followed by the synthesis in 1993 of single walled carbon nanotubes (SWCNT) of truly nanometric diameters [2,3]. In the meantime, large efforts have been devoted to the study of boron-nitride nanotubes [4] and many different inorganic nanotubes [5-9]. Their physicochemical properties are recognized to be appealing for next-generation devices that could outperform current technologies for nanoelectronics [10], nanofluidics [11], selective molecular sieving [12], energy conversion [13,14], catalytic nanoreactors [15] and carriers for the sustained release of active molecules [16-18], to highlight a few. However, most of these applications require controlling at the nanometer scale, the nanotube dimensions (pore size and length), their interface properties as well as their organization, by using straightforward approaches if possible. In this context, having the possibility to synthesize nanotubular structures with desired size and interfaces would be a major step forward in exploring physical concepts in a controlled manner.

Among the wide variety of inorganic nanotubes, imogolite nanotubes (INTs) can boast having these unique and versatile properties. Belonging to clay minerals, these aluminosilicate minerals consist of a curved octahedral $\left[\mathrm{Al}(\mathrm{OH})_{3}\right]$ layer on which isolated $\left[\mathrm{SiO}_{3}(\mathrm{OH})\right]$ tetrahedron units are connected upright to the octahedral vacancy via covalent bonding between three mutual oxygen atoms (Figure 1). INT structure can hence be described as a three-dimensional $(\mathrm{OH})_{3} \mathrm{Al}_{2} \mathrm{O}_{3} \mathrm{Si}(\mathrm{OH})$ elementary unit arranged in a hexagonal lattice [19]. It is worth noting that imogolite structure is very different from the one of halloysite, another clay nanotube ubiquitous in soils and weathered rocks, where the curved octahedral $\left[\mathrm{Al}(\mathrm{OH})_{3}\right]$ layer forms the internal surface of the nanotubes whereas the external surface is composed of Si-O-Si groups [7]. These differences are certainly at the root of the unique properties of imogolite nanotubes. 


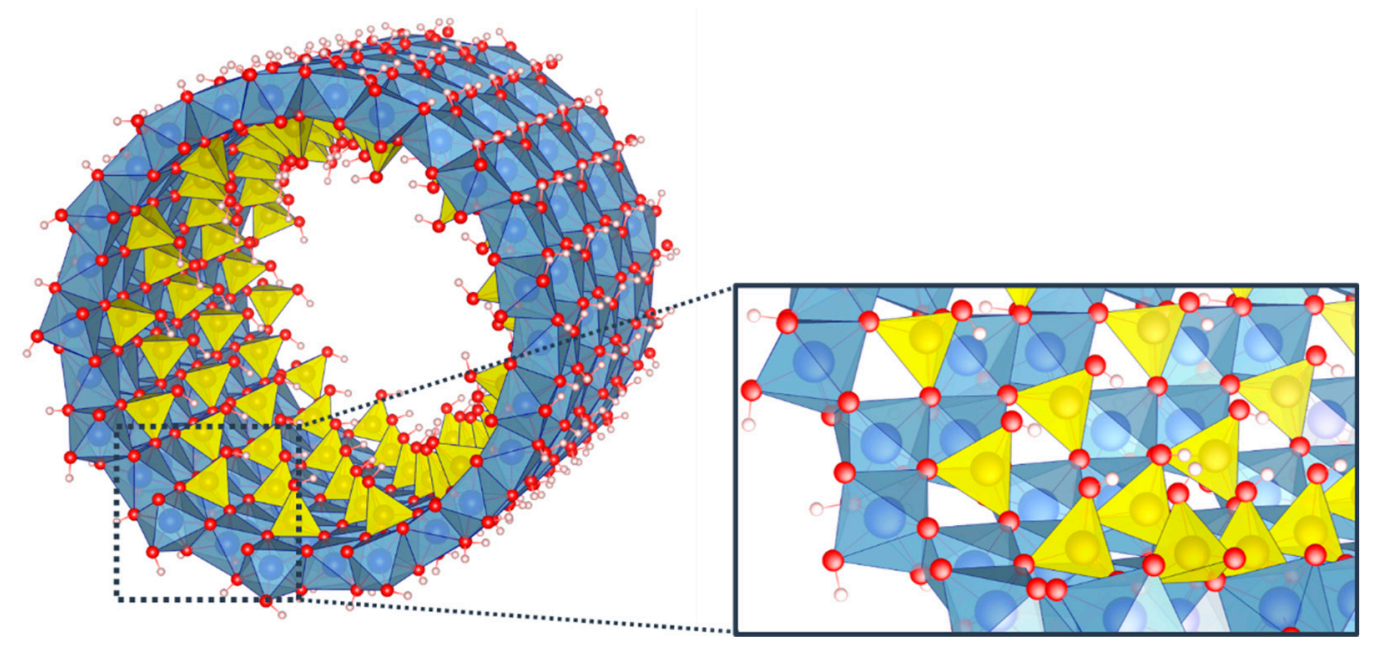

Figure 1. Structure of a single-walled imogolite nanotube and detail of the arrangement of tetrahedron units on the octahedral vacancies. Color code: aluminum (blue); silicon (yellow); oxygen (red); hydrogen (white).

With inner diameters in the nanometer range $(1-3 \mathrm{~nm})$, INTs represent one of the most promising inorganic analogs of SWCNTs. Naturally formed from weathered volcanic glass either on Earth [20] or Mars [21], INTs can also be synthesized easily by using low-temperature sol-gel methods [22]. The advantage of INTs originates from a well-defined minimum in the strain energy of the structure [23-27], allowing the production of samples with monodisperse diameter [28,29] and chirality [30], contrarily to other nanotubes where the strain energy decreases monotonically with increasing diameters [31,32]. Coupled with the possibility to adjust either their morphology (single (SW) vs. double-walled (DW) structures, aspect ratio) and surface properties by changing only the nature of the precursors, the synthesis of INT thus offers a convenient and simple way to obtain diameter-controlled nanotubes with functional interfaces. Therefore, they started to be applied in a wide range of potential applications.

Through studies conducted over the last two decades, this review aims to demonstrate how the imogolite nanotubes represent a promising candidate for up-to-date nanotechnological applications. We will first focus here on the recent developments for INT synthesis and their unique properties, particularly in terms of morphological control and surface functionalization. The interested reader is referred to [33,34] for recent reviews on the formation mechanisms, structure and properties of nanotubular clay minerals (imogolite and halloysite). The unique features of INTs will then be illustrated through recent applications and future prospects.

\section{Imogolite Synthesis}

\subsection{Synthesis Routes for Aluminosilicate INTs}

The synthesis of single-walled imogolite nanotubes (SWINT) was first reported by Farmer et al. in 1977 [22]. It consists of the co-precipitation under vigorous stirring of $\mathrm{Al}$ and Si precursors. This solution is adjusted to $\mathrm{pH} 5$ with the addition of $\mathrm{NaOH}$, and then immediately re-acidified to pH 4.5 with a mixture of $\mathrm{HCl}$ and acetic acid (Figure 2). Finally, the solution is aged upon heating under reflux or in autoclave. Since then, several improvements have been proposed in the literature by changing either the nature of the precursors, their initial concentration, their ratio (e.g., the hydrolysis ratio $\mathrm{R}=[\mathrm{OH}] /[\mathrm{Al}])$ or the reaction pathway [35-41]. Among them, Denaix et al. obtained similar INTs as those reported previously, but without performing the acidification stage [38]. In that case, the hydrolysis step was directly controlled initially by adjusting the amount of $\mathrm{NaOH}$ added (typically $\mathrm{R}=2$, Figure 2). Most of the current studies dealing with INTs use one of the two protocols presented 
in Figure 2, with minor variations more or less. For instance, the $[\mathrm{Al}] /[\mathrm{Si}]$ ratio is set between 1.5 and 2 , a slight excess of Si precursor preventing the formation of aluminum hydroxides such as gibbsite and boehmite [36]. A "seeding" approach has also been explored by adding a certain amount of a processed synthetic imogolite sol in a solution of $\mathrm{Al}$ and Si precursors [42,43]. Although it avoids the $\mathrm{pH}$ adjustment step and allows the imogolite formation after heating the mixture for 2 days, this synthesis route remained quite confidential and has not yet been explored in detail.

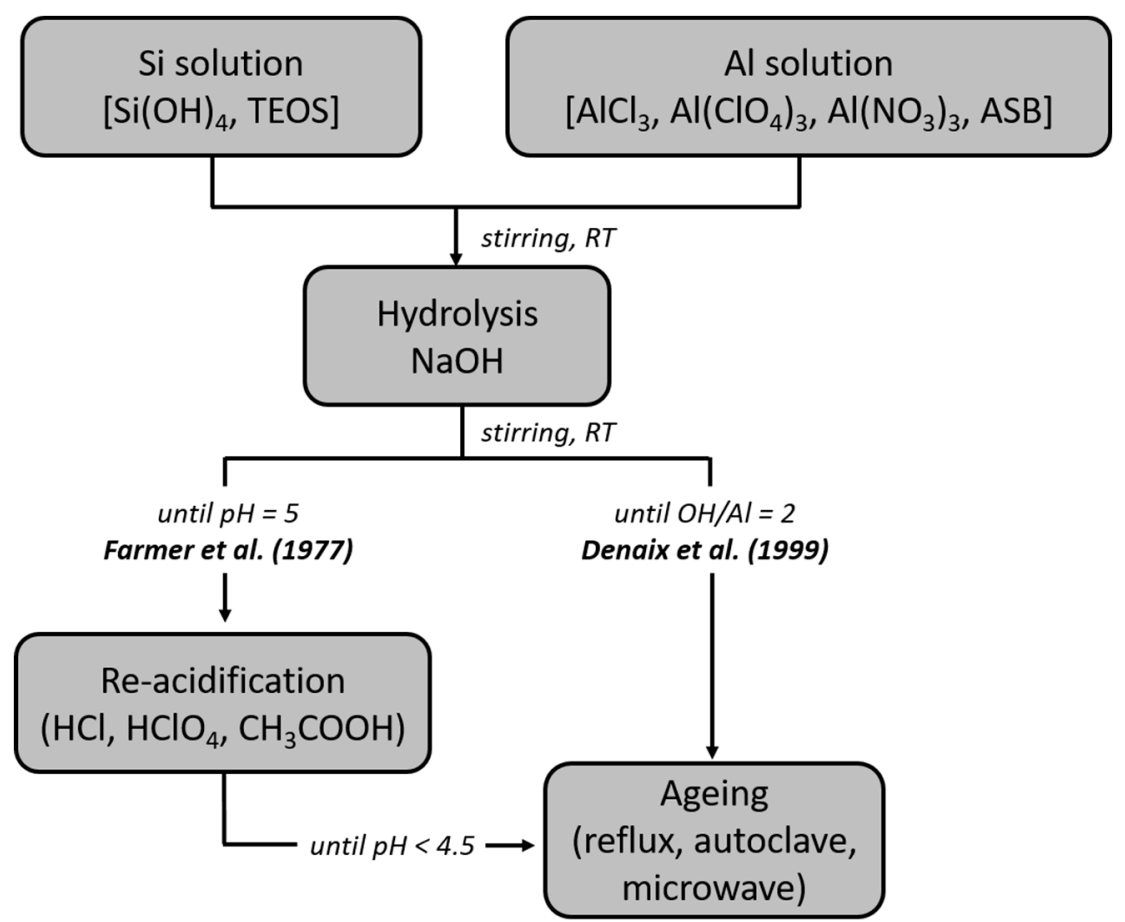

Figure 2. Flowchart for the two main synthesis methods of imogolite nanotubes: Farmer et al. [22]; Denaix et al. [38]. TEOS: tetraethylorthosilicate; ASB: Aluminum tri-sec-butoxide.

\subsection{The Selection of Precursors}

The sources of $\mathrm{Al}$ and $\mathrm{Si}$ precursors have also been varied. INT synthesis are commonly performed with $\mathrm{Al}\left(\mathrm{ClO}_{4}\right)_{3}, \mathrm{AlCl}_{3}$ and $\mathrm{Al}$ alkoxide (ASB: aluminum tri-sec-butoxide), $\mathrm{Al}\left(\mathrm{NO}_{3}\right)_{3}$ salt being less employed, while the silicon precursor is most often $\mathrm{Si}(\mathrm{OH})_{4}$ or an alkoxide (TEOS: tetraethoxysilane) [40]. However, regardless of the nature of the $\mathrm{Al}$ and $\mathrm{Si}$ precursors used, the synthetic imogolite nanotubes are always identical with inner and outer diameters of 1 and $2.5 \mathrm{~nm}$, respectively. Conversely, Yucelen et al. suggested that the nature of the protic acid used $\left(\mathrm{HCl}, \mathrm{HClO}_{4}\right.$ or $\left.\mathrm{CH}_{3} \mathrm{COOH}\right)$ may control the relationship between the INT precursor's shape, formed in the early stage of the synthesis (also referred as "proto-imogolite"), and the resulting nanotube shapes [44]. More recently, Arancibia-Miranda et al. evidenced that replacing $\mathrm{NaOH}$ with $\mathrm{KOH}$ strongly impacts the morphology of the nanotubes in addition to producing a large amount of disordered structures [45]. INT diameter slightly increases by less than $20 \%$ while their average length becomes shorter, suggesting that the nature of the counter ions affects the hydrolysis of $\mathrm{Al}$ and Si precursors [46,47].

\subsection{Effects of Ge Substitution}

One of the most blatant examples of progress in INT synthesis arises from the isomorphic substitution of silicon by germanium $[48,49]$. Beyond a twofold increase in external diameter, replacing TEOS with a Ge alkoxide (e.g., TEOG: tetraethoxygermane) enables producing concentrated (molar) suspensions of Ge-imogolite analogues [50], an important key step towards large scale applications. Maillet et al. observed that the initial concentration of aluminum salt $\left(\mathrm{C}_{\mathrm{Al}}\right)$ controlled the resulting 
nanotube shape, producing either double-walled (Ge-DWINT, $\mathrm{C}_{\mathrm{Al}}<0.4 \mathrm{~mol} \cdot \mathrm{L}^{-1}$ ) or single-walled nanotubes (Ge-SWINT, $\mathrm{C}_{\mathrm{Al}}>0.75 \mathrm{~mol} \cdot \mathrm{L}^{-1}$ ) [51]. The mechanism involved seems to be a subtle balance between attractive and curvature energies during the early stage of the synthesis [51,52]. More interestingly, the energy minimum in the strain energy depends on the substitution ratio $[\mathrm{Si}] /([\mathrm{Si}]+$ [Ge]) and allows us to predict the INT diameters with respect to the initial synthesis conditions [53,54]. In contrast to Si-INTs, Ge-analogues form short nanotubes with a reduced length $(<100 \mathrm{~nm})[29,49,54]$. On the other hand, Amara et al. demonstrated that micron-long Ge-INTs can be synthesized by using the thermal decomposition of urea $\left(\mathrm{CO}\left(\mathrm{NH}_{2}\right)_{2}\right)$ to produce hydroxyl ions instead of the slow injection of $\mathrm{NaOH}$ [55]. Hence, the synthesis of $(\mathrm{OH})_{3} \mathrm{Al}_{2} \mathrm{O}_{3} \mathrm{Si}_{x} \mathrm{Ge}_{1-x}(\mathrm{OH})$ INT provides us with a unique system of 1D nanostructures with monodisperse sizes and changeable aspect ratio (Figure 3).

\section{a}

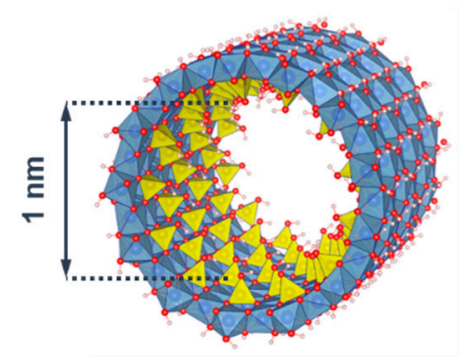

b

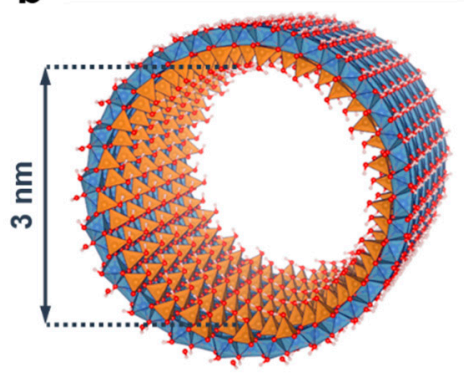

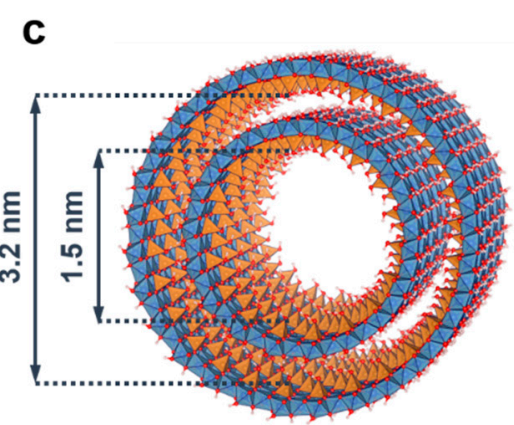

Figure 3. Inner diameter size for the different endmembers of $(\mathrm{OH})_{3} \mathrm{Al}_{2} \mathrm{O}_{3} \mathrm{Si}_{x} \mathrm{Ge}_{1-x}(\mathrm{OH})$ imogolite nanotubes. (a) Si-SWINT; (b) Ge-SWINT; (c) Ge-DWINT. Color code: aluminum (blue); silicon (yellow); germanium (orange); oxygen (red); hydrogen (white).

\section{Surface Properties and Modifications}

\subsection{Colloidal Behavior}

The structure of INTs with inner and outer hydroxyl groups makes them excellent candidates for colloidal dispersions. Gustafsson moved forward with a unique intrinsic polarization, the isolated $-\mathrm{SiOH}$ groups on the inner cavity developing a negative charge, whereas the-AlOHAl groups along the external tube walls bear a weak positive charge [56]. This model has been subsequently corroborated by numerical simulations [24], showing no dependence on the substitution ratio [Si]/([Si] + [Ge]) [25]. Thanks to the surface charge, INTs are easily dispersed in polar solvents to form stable colloidal suspensions $[57,58]$. Furthermore, the possibility to varying both nanotube aspect ratio (through the synthesis conditions) and electrostatic interactions $(\mathrm{pH}$, ionic strength, ... ) allows controlling, directly in aqueous phase, the self-organization of imogolite nanotubes from a liquid sol to arrested phases [59-61], making such nanotubes suitable for a wide range of solution processes. Similarly, it is also possible to control the nanotube arrangement in the solid state during the drying process. For instance, powders of Ge-SWINT tend to form large bundles on a 2D hexagonal lattice if they are processed from suspensions prepared at an ionic strength higher than $\sim 10^{-3} \mathrm{~mol} \cdot \mathrm{L}^{-1}$ [61]. Interestingly, this kind of organization also induces significant radial deformations of the cross section, INTs having a regular hexagonal shape instead of a cylindrical one [62]. Another unique feature of INTs is the high surface density of hydroxyl groups $\left(\sim 18 \mathrm{OH} / \mathrm{nm}^{2}\right)$, considering the atomic structure reported in [19], which offers multiple binding environments and renders the surface very hydrophilic with high water retention capacity [63-65]. INTs were recognized as good adsorbents very early on, especially in environmental contexts where they interact strongly with ions [38,66-70].

Despite these benefits, the presence of water inside INTs might hinder or block the diffusion of other interest molecules $\left(\mathrm{CO}_{2}, \mathrm{CH}_{4}, \ldots\right)$. Similarly, in the field of nanocomposites, the effective dispersion of nanoparticles must be achieved only by modifying their surface to make it compatible 
with the organic matrix. Hence, significant efforts have been undertaken in order to make INTs suitable with the intended applications.

\subsection{Modification of the Inner Cavity}

Two strategies have been applied for the inner modification of hydrophilic imogolite nanotubes, namely (i) post-synthesis or (ii) direct synthesis chemical procedures. The list of the different coupling agents is summarized in Table 1.

Table 1. Coupling agents used for inner modification (tetrahedral sites) of imogolite nanotubes (INT).

\begin{tabular}{|c|c|c|c|c|}
\hline Compound & Acronym & Strategy $^{a}$ & INT & Refs. \\
\hline (3-aminopropyl)triethoxysilane & APTES & post. & $\mathrm{Si}$ & [71] \\
\hline (aminomethyl)triethoxysilane & AMTES & direct & $\mathrm{Si}$ & [72] \\
\hline \multirow{2}{*}{ Methyltrimethoxysilane } & \multirow{2}{*}{ MTMS } & post. & $\mathrm{Si}$ & [73] \\
\hline & & direct & $\mathrm{Si}$ & [74] \\
\hline Methyltriethoxysilane & MTES & direct & $\mathrm{Si}$ & {$[30,74-78]$} \\
\hline Trichlorosilane & TCIS & post. & $\mathrm{Si}$ & [73] \\
\hline Acethyl chloride & $\mathrm{AcCl}$ & post. & $\mathrm{Si}$ & [73] \\
\hline Methyltriethoxygermane & MTEG & direct & $\mathrm{Ge}$ & {$[30,77]$} \\
\hline
\end{tabular}

Johnson \& Pinnavaia were the first to report the functionalization of imogolite nanotubes in an attempt to obtain organosilane derivatives of INTs for their intercalation as pillaring agents with montmorillonites [71]. Silanyzation reactions are carried out in aqueous solutions. Post-functionalization has also been completed after a perfect dehydration of the hydrophilic INT samples in presence with different silane agents (MTMS, TCIS, AcCl) [73]. However, in both cases, the degree of inner surface substitution was lower than $35 \%$.

A more convenient way is the direct, template-free synthesis of imogolite nanotubes with the desired functional moieties by simply replacing the initial alkoxide (prefiguring the tetrahedral layer) by a functionalized one. Bonelli's group was the first to succeed in synthesizing methyl-modified Si-SWINT by using methyltriethoxysilane (MTES) [75,76], a method that is still the most widely used currently $[30,74,77,78]$. In a similar manner, Kang et al. reported a single-step approach to synthesize hybrid Si-SWINT with a 15\% aminomethyl group substitution on the inner cavity, via the design of a specific organosilane precursor (Figure $4 a$ a) [72]. In both cases $\left(-\mathrm{CH}_{3}\right.$ and $\left.-\mathrm{CH}_{2} \mathrm{NH}_{2}\right)$, the chemical modification leads to a large enhancement in molecular adsorption selectivity.

It is worth noting that all these studies concern only Si-based imogolite nanotubes. As stated before, the diameter of INT increases continuously with the substitution of Si by Ge [53,54]. Similar behavior could therefore be expected in the case of methyl-modified INTs by using a mixture of MTES and MTEG (methyltriethoxygermane). Such an assumption has been confirmed by Amara et al. [77]. It was shown by X-ray scattering measurements (XRS) that the continuous methylation of INTs can be obtained from Si to Ge endmembers (Figure $4 \mathrm{~b}$ ), but most importantly that the inner diameter size increases progressively $(1.8-2.5 \mathrm{~nm})$. In addition, Monet et al. recently revealed that methylation of the inner cavity not only offers control over the surface properties, but it also leads to a drastic structural change of the chiral vector of the nanotube, with the armchair configuration being energetically favored over the zigzag structuring [30]. 
a

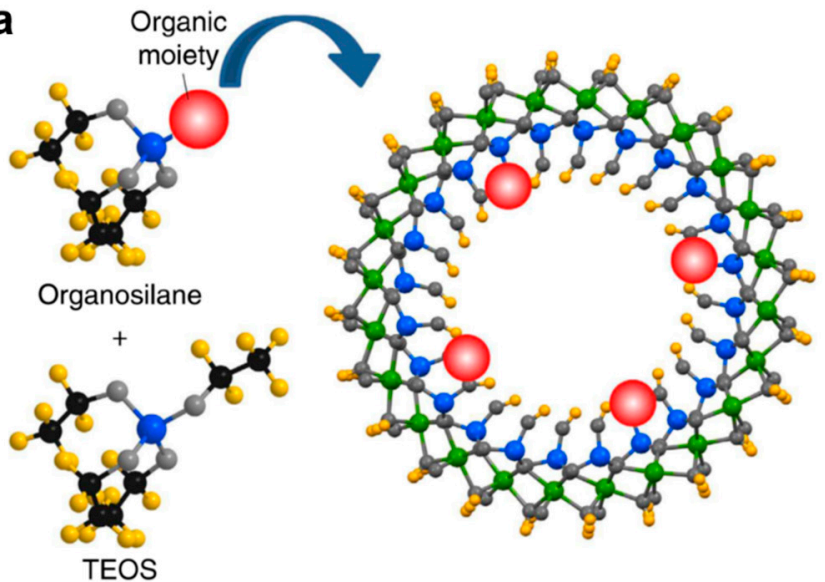

b

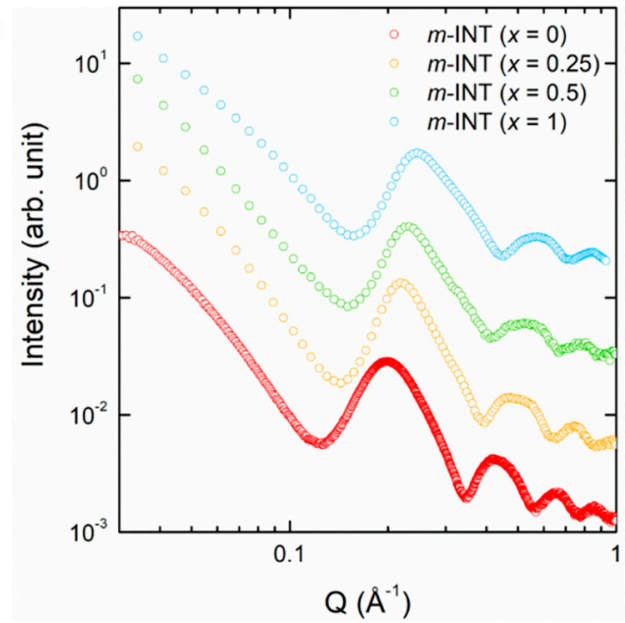

Figure 4. (a) Direct synthesis of hybrid imogolite nanotubes with functionalized alkoxides $\mathrm{M}-\mathrm{R}\left(\mathrm{OC} 2 \mathrm{H}_{5}\right)_{3}$ with $\mathrm{M}=\mathrm{Si}$, $\mathrm{Ge}$ and $\mathrm{R}=-\mathrm{CH}_{3},-\mathrm{CH}_{2} \mathrm{NH}_{2}$. (b) $\mathrm{X}$-ray scattering (XRS) diagrams obtained on methyl-functionalized single-walled $(\mathrm{OH})_{3} \mathrm{Al}_{2} \mathrm{O}_{3} \mathrm{Si}_{x} \mathrm{Ge}_{1-x}\left(\mathrm{CH}_{3}\right)$ at different substitution ratio $x$ $=[\mathrm{Si}] /([\mathrm{Si}]+[\mathrm{Ge}])$. XRS diagrams shift progressively upon substitution of Si by Ge, indicating an increase of the nanotube diameter. Adapted with permissions from [72,77].

\subsection{Modification of the Outer Surface of Imogolite}

Modification of the external surface of imogolite has been strongly explored, mainly to render them compatible with another phase. As with the chemical modification of the INT inner cavity, the large density of hydroxyl groups offers a wide range of possibility for surface anchoring and numerous chemical pathways have been proposed with varying degrees of success (Table 2).

Table 2. Main functionalization routes of the outer wall of imogolite nanotube (INT).

\begin{tabular}{|c|c|c|c|c|}
\hline Functional Group & Compound & Acronym & INT & Refs. \\
\hline \multirow{3}{*}{ Silane } & (3-aminopropyl)triethoxysilane & APTES & $\mathrm{Si}$ & {$[71,76,79,80]$} \\
\hline & (3-chloropropyl)triethoxysilane & CTES & $\mathrm{Si}$ & [81] \\
\hline & (3-mercaptopropyl)trimethoxysilane & MPTMS & $\mathrm{Si}$ & {$[82]$} \\
\hline \multirow{8}{*}{ Phosphonate } & Octadeculnhosnhonis acid & ARPA & $\mathrm{Si}$ & [83-87] \\
\hline & Uctadecylphosphonic acid & ODPA & $\mathrm{Ge}$ & [88] \\
\hline & Tetradecylphosphonic acid & TDPA & $\mathrm{Si}$ & [85] \\
\hline & Vinylphosphonic acid & VPA & $\mathrm{Si}$ & [86] \\
\hline & Dodecylphosphate & DDPO4 & $\mathrm{Si}$ & [89] \\
\hline & 2-Acidphosphoxyethyl methacrylate & P-HEMA & $\mathrm{Si}$ & [90] \\
\hline & Terthiophenes derivatives & НТЗР НТЗОР & $\mathrm{Si}$ & [91] \\
\hline & 8-(2-bromo-2-methylpropanoyloxy)octylphosphate & $\mathrm{BMPOPO}_{4}$ & $\mathrm{Si}$ & [92] \\
\hline \multirow{2}{*}{ Carboxylate } & Stearic acid & SA & $\mathrm{Si}$ & [84] \\
\hline & Dicarboxylic acid & DA & $\mathrm{Si}$ & {$[93,94]$} \\
\hline Sulfonate & $\begin{array}{l}\text { Poly[disodium 2,5-bis(3-sulfonatopropoxy)- } \\
\text { 1,4-phenylene-alt-1,4-phenylene) }\end{array}$ & WS-PPP & $\mathrm{Si}$ & [95] \\
\hline \multirow{5}{*}{ Others } & 4-(hydroxyethylthioacetyl)catechol & HETAC & $\mathrm{Si}$ & [96] \\
\hline & Benzaldehyde & BA & $\mathrm{Si}$ & {$[97]$} \\
\hline & Polypyrrole ${ }^{a}$ & ppy & $\mathrm{Si}$ & {$[98,99]$} \\
\hline & $\gamma$-ray irradiation (peroxides) & - & $\mathrm{Si}$ & {$[100,101]$} \\
\hline & Isomorphic substitution $(\mathrm{Al} \rightarrow \mathrm{Fe})$ & Fe-INT & $\begin{array}{c}\mathrm{Si} \\
\mathrm{Ge}\end{array}$ & $\begin{array}{c}{[102-106]} \\
{[107]}\end{array}$ \\
\hline
\end{tabular}

${ }^{a}$ Grafted by chemical vapor deposition (CVD).

The first attempt was performed by Johnson and Pinnavaia via silanization of Si-SWINT with APTES [71,79]. Zanzottera et al. evidenced a selective functionalization of APTES towards only the 
outer surface of the nanotubes by employing INTs with a methyl-modified inner cavity, while the silane anchoring groups remain unreactive with the $\mathrm{Si}_{-} \mathrm{CH}_{3}$ entities [76]. However, APTES moieties remain hydrolytically labile and are totally removed after several days of dialysis [71,79]. Such behavior may explain why the reusability of APTES-OsO4 complex grafted on Si-SWINT is severely degraded after their first use [80]. In contrast, the use of other silanes does not seem to induce such drawbacks [81,82].

The most common way to modify a metal oxide surface is likely by using phosphonates, sulfonates and carboxylates derivatives [108]. Takahara's group was one of the first to modify the external surface of an INT with different alkyl phosphonic acids (Table 2) [83-85,89,90]. As a proof-of-concept, such functionalized INTs are easily dispersed into hydrophobic solvents (Figure 5a) [83,86,88,90], display weaker adhesion forces [83,84], present self-organization behaviors either at the air/water [85] or water/oil interfaces [87] as well as higher static contact angle than unmodified nanotubes [89] and may display enhanced conductivity [91]. Since then, more complex approaches have been implemented, in particular to realize a surface-initiated polymerization of methyl methacrylate (MMA), the initiator of the polymerization process being specifically designed with a phosphate group (Figure 5b) [92].

a

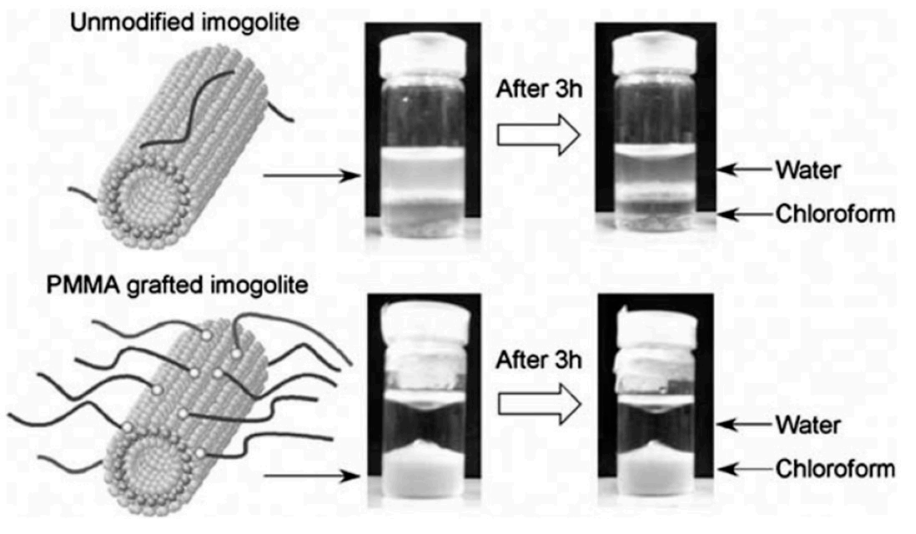

b

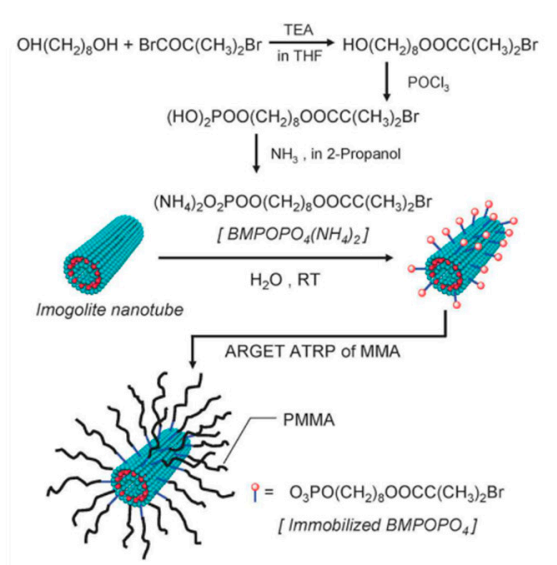

Figure 5. Illustration of outer surface modification of imogolite nanotubes. (a) Dispersion state of unmodified and poly(methylmethacrylate) (PMMA) grafted single-walled aluminosilicate imogolite nanotubes (Si-SWINT) in water/chloroform mixtures. (b) Flowchart of the modification and the immobilization of the initiator $\left(\mathrm{BMPOPO}_{4}\right.$, see Table 2) used for surface-initiated polymerization of methyl methacrylate (MMA). Adapted with permissions from [90,92].

Similar to phosphonates, the carboxylates and sulfonates moieties are reported to strongly interact with the -Al-OH groups of INTs [84], resulting in homogeneous hydrogels exhibiting thixotropic behavior [93], hierarchical ordering [94] and modified optical properties [95]. Grafting of other functional groups have also been reported, using chemisorption [96,97], chemical vapor deposition (CVD) $[98,99]$, or $\gamma$-ray irradiation, the latter being used to generate peroxide groups for subsequent monomer polymerization) $[100,101]$.

\section{Applications}

It is well recognized that imogolite nanotubes remain insulating materials with large band gaps. To tackle this issue, structural modification of the outer wall has also been conducted this time by isomorphic substitution of $\mathrm{Al}^{3+}$ by $\mathrm{Fe}^{3+}$ [102-107]. The effect of Fe incorporation acts as specific coordination centers for organic moieties and leads to higher adsorption efficiency [104,105], while altering the electronic properties of the nanotubes even for low substitution rates [109]. Other isomorphic substitutions have been explored, on the theoretical background, by replacing both $\mathrm{Al}$ and Si atoms by elements of groups III (Ga, In) \& IV (C, Ge, Sn) respectively [110], or by substituting the inner tetrahedrons by phosphorous and arsenic derivatives [111]. 
The purpose of this section is to provide the reader with a concise but comprehensive overview of the applications that have been explored for this class of nanotubular clay minerals. Because of its unique structure with well-defined porosity and interfaces, INTs were first recognized as a molecular sieving material. A large number of studies have been devoted to gas adsorption of neutral and reactive molecules. Molecules interact mainly with the inner silanol (germanol) sites, which are accessible only after careful pretreatment to remove confined water [112]. The tetrahedral sites present interesting acidic properties, which enhance interactions with adsorbed molecules such as $\mathrm{NH}_{3}$, benzene, $\mathrm{CO}$, $\mathrm{CO}_{2}$ and $\mathrm{CH}_{4}$ (Figure 6a) $[43,64,72,75,112-116]$. Recent results show that modification of the inner surface of INTs results in dramatically enhanced $\mathrm{CO}_{2} / \mathrm{CH}_{4}$ and $\mathrm{CO}_{2} / \mathrm{N}_{2}$ selectivity $[72,75,113]$. Several works also demonstrate that hybrid INTs, dispersed in a liquid medium, spontaneously confine inside them organic molecules added to the suspension [77,87].
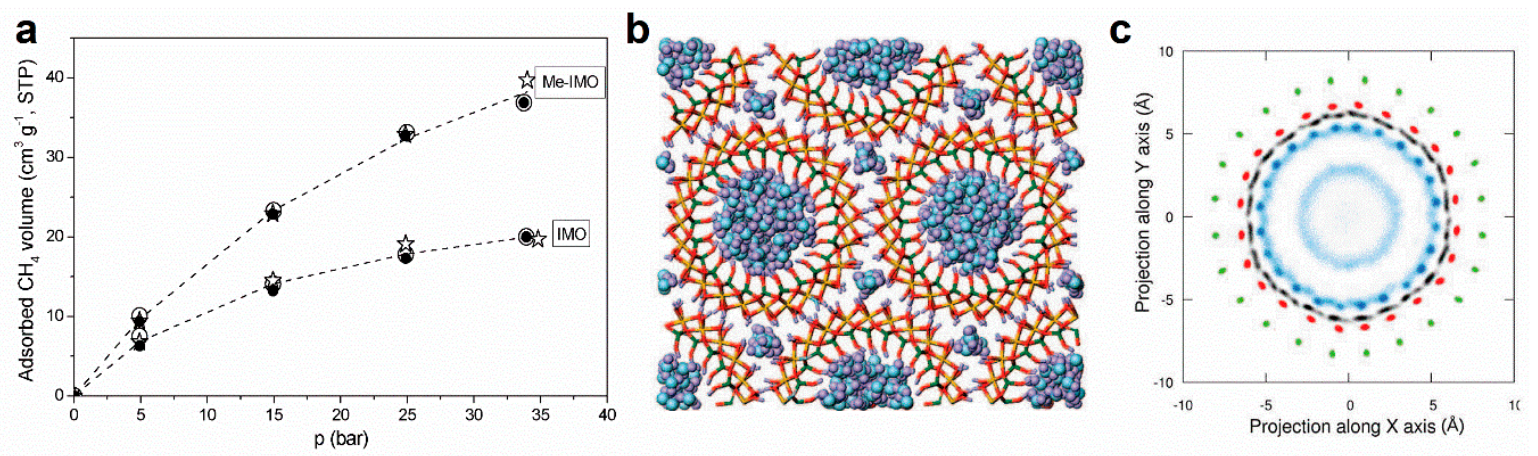

Figure 6. Molecular confinement in imogolite nanotubes. (a) Selective molecular sieving towards $\mathrm{CH}_{4}$. Adapted from [75]; (b,c) Snapshot of fully hydrated INTs and 2D radial density profiles for oxygen (blue) from water molecules. Adapted with permissions from $[117,118]$.

The peculiar structure of INTs also offers a unique opportunity to understand deeply the structural and dynamical properties of water confined in relation to the nature of the interface and at the nanometer scale. They certainly deserve comparison with, for instance, carbon nanotubes (CNT) which present unique transport properties $[11,12,119,120]$. Despite the excitement generated by this topic for carbon nanostructures, there is little experimental data available on water confined inside INTs up to now. Water vapor adsorption isotherms reveal strong water uptake at low relative pressure $(20 \mathrm{wt} \%$ at $\left.\mathrm{P} / \mathrm{P}_{0}<0.2\right)$ followed by a pseudo-plateau up to $\mathrm{P} / \mathrm{P}_{0}=0.85(30 \mathrm{wt} \%)$ [64]. Water structuring was recently investigated during the filling of INTs by infrared spectroscopy. Unlike CNTs [121,122], these experiments suggested that the silanol pending groups played a non-negligible role in the way in which water molecules interact with the inner wall [123]. In contrast, the properties of water confined in INTs has been mainly investigated on the theoretical background. Molecular dynamics simulations revealed the predominant hydrophilicity character of the inner surface of INTs (Figure 6b) [65,117,124]. Indeed, radial density profiles suggested a strong structuration of water molecules in specific adsorption sites with complex interactions with adjacent molecules (Figure 6c) [118]. Furthermore, the simulations confirmed the key role of the inner pending function, whose flexibility is critical in the adsorption of hydrogen-bonding molecules [124]. Hence, INTs could be used as tunable building blocks for filtration applications.

Since the successful reinforcement of nylon by clay minerals in 1993 [125], new clay/polymer nanocomposites have emerged during the last two decades [126,127]. In the case of imogolite nanotubes, effective reinforcement was also extensively explored by using colloidal properties of INTs either for un-modified nanotubes or after functionalization of the outer wall to facilitate their dispersion in the desired polymer matrix (Table 3). 
Table 3. Type of polymer used for nanocomposites preparation with INTs.

\begin{tabular}{|c|c|c|c|c|}
\hline Type of Polymer & Acronym & Form & INT & Refs. \\
\hline Poly(vinyl alcohol) & PVA & $\begin{array}{c}\text { Film } \\
\text { Fiber } \\
\text { Membrane }\end{array}$ & $\begin{array}{l}\mathrm{Si} \\
\mathrm{Si} \\
\mathrm{Si}\end{array}$ & $\begin{array}{c}{[84,128-131]} \\
{[132]} \\
{[133-135]}\end{array}$ \\
\hline Poly(methyl methacrylate) & PMMA & Film & $\mathrm{Si}$ & [90] \\
\hline Poly(E-caprolactone) & PCL & $\begin{array}{c}\text { Film } \\
\text { Hydrogel }\end{array}$ & $\begin{array}{l}\mathrm{Si} \\
\mathrm{Si}\end{array}$ & $\begin{array}{l}{[96]} \\
{[97]}\end{array}$ \\
\hline Poly(lactic acid) & PLA & Hydrogel & $\mathrm{Si}$ & [97] \\
\hline Poly(butylene succinate) & PBS & Hydrogel & $\mathrm{Si}$ & [97] \\
\hline Poly(acrylic acid) & PAA & $\begin{array}{c}\text { Hydrogel }^{\text {a }} \\
\text { Hydrogel }\end{array}$ & $\begin{array}{l}\mathrm{Si} \\
\mathrm{Si}\end{array}$ & $\begin{array}{c}{[100,101,136]} \\
{[137]}\end{array}$ \\
\hline Poly(hydroxyethyl acrylate) & PHEA & Hydrogel & $\mathrm{Si}$ & [137] \\
\hline Poly(vinyl chloride) & PVC & Film & $\mathrm{Si}$ & [138] \\
\hline Polystyrene & PS & Film & $\mathrm{Si}$ & [139-142] \\
\hline Polyamide & PA & $\begin{array}{l}\text { Hydrogel } \\
\text { Membrane }\end{array}$ & $\begin{array}{l}\mathrm{Si} \\
\mathrm{Si}\end{array}$ & $\begin{array}{c}{[137,143,144]} \\
{[145-147]}\end{array}$ \\
\hline Dicarboxilic acid & DA & Hydrogel & $\mathrm{Si}$ & {$[93,94,148,149]$} \\
\hline Hydroxypropyl cellulose & HPC & Film & $\mathrm{Si}$ & [150] \\
\hline Poly(hexylthiophene) & P3HT & Fiber & $\mathrm{Si}$ & [151] \\
\hline Sugar alcohol & Isomalt & Fiber & Ge & [152] \\
\hline Biopolymers & & $\begin{array}{l}\text { Hydrogel } \\
\text { Film }\end{array}$ & $\begin{array}{l}\mathrm{Si} \\
\mathrm{Ge}\end{array}$ & $\begin{array}{c}\text { [153-159] } \\
{[160]}\end{array}$ \\
\hline
\end{tabular}

${ }^{\text {a }}$ Grafted by $\gamma$-irradiation.

Poly(vinyl alcohol) (PVA) is by far the most used polymeric material since PVA/INT can be processed easily from aqueous solutions. In most cases, the mechanical and optical properties of the resulting composite are enhanced, whether in film [84,128-131], fiber [132] or membrane form [133-135] (Figure 7a). Beyond PVA, INT has been incorporated in a wide variety of polymer matrix (Table 3) either for nanotube-reinforced nanocomposites $[90,96,100,138,143,149,150]$ with anisotropic structural properties (Figure 7b) $[93,94,97,136,137,144,148,151,152]$, fabrication of hierarchical porous structures [139-142] or the encapsulation/sustained-release of biomolecules for medical applications (Figure 7c) [153-159].
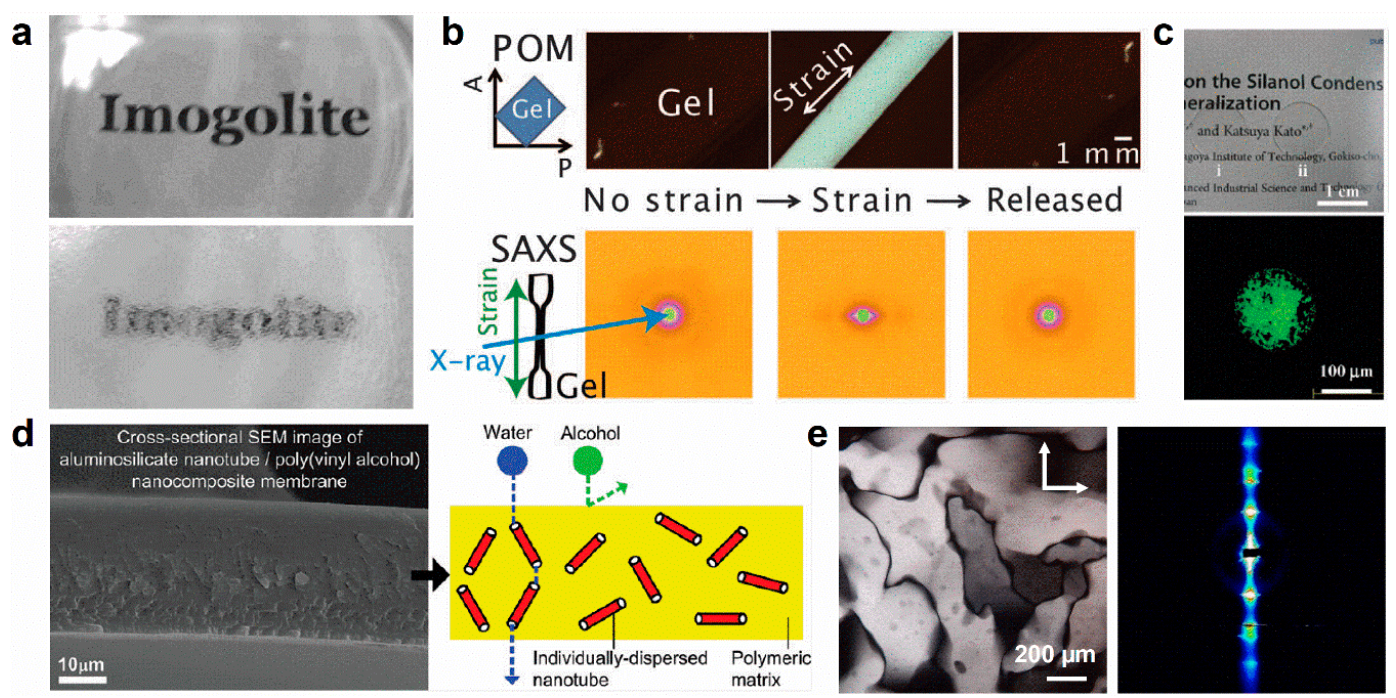

Figure 7. Applications of imogolite for designing new $(\mathbf{a}-\mathbf{c})$ hybrid nanocomposites, (d) filtration membranes or (e) liquid crystals. (a) Transparency of in situ synthesized (top) or blend (bottom) PVA/ 
INT films. Adapted with permissions from [128]; (b) Reversible structural transition of INT hydrogels upon stretching. Adapted with permissions from [148]; (c) Encapsulation of laccase in INT hydrogel and its activity. Adapted with permissions from [153]. (d) PVA/INT membrane for molecular separation. Adapted with permission from [133]. (e) Alignment of a liquid-crystal columnar phase of INTs under electric field. Adapted with permissions from [60].

Beyond their use as nanofillers, INTs present a great potential for water osmosis desalination [161]. The control of nanotube diameter and interface combined with the possibility to capture molecules in a selective manner confer to these tubular structures a wide range of potential applications, from filtration to depollution of water. By combining these properties with the ability of INTs to be dispersed in a polymer matrix, the fabrication of (ultra)thin film nanocomposite (TFN) membranes has started to receive more intention recently (Figure $7 d$ ) $[133,135]$. Several studies reported that the addition of INTs in TFN substantially increased the water throughput due to preferential water flow through imogolite nanotubes $[133,134,145-147]$. Thanks to the permanent polarization of INTs with negative charges on the inner surface, significant ion exclusion can be achieved $[134,145,147]$ due to the combination of steric hindrance and electrostatic repulsion as shown previously for CNTs [162].

We have shown that INT can be regarded as inorganic counterparts of carbon nanotubes in terms of morphology and aspect ratios [51,55]. However, a major difference between INT and CNT is that the former is readily water-soluble thanks to their electrical surface charge, in contrast with the latter. As expected for highly elongated colloidal nanorods, an isotropic to nematic liquid-crystal (LC) phase transition can occur in suspensions of INTs [163], which is the result of a competition between orientational entropy and the packing entropy governed by excluded-volume interactions [164]. Surprisingly, very dilute suspensions of INTs also form a columnar liquid-crystal (Figure 7e) [60]. Despite the high dilution, the nanotubes are perfectly organized on a hexagonal lattice with large spacing. This dilute liquid-crystal has such low visco-elasticity that the nanotubes are easily aligned in an electric field (Figure 7e), which is a significant advantage for the elaboration of anisotropic nanocomposite materials or the development of electro-optic devices.

As far as nanodevices are concerned, it has been suggested that INT can be used for nanoelectronic applications by altering their insulating behavior through surface modifications $[98,99,104]$. Hence, thin film INTs have been proposed as field emission electrodes for use as water sensors [165] or electrocatalytic activity [166] (Figure 8a). Another behavior of imogolite nanotubes is their ability to immobilize metalloids, nanoparticles and dyes on specific sites on the external surface (Figure 8b) [37, $38,167-169]$, which open new ways towards water treatment $[69,81,82,105,170]$, antimicrobial agents and their use in transparent dressings [171-173] or for catalysis [174].
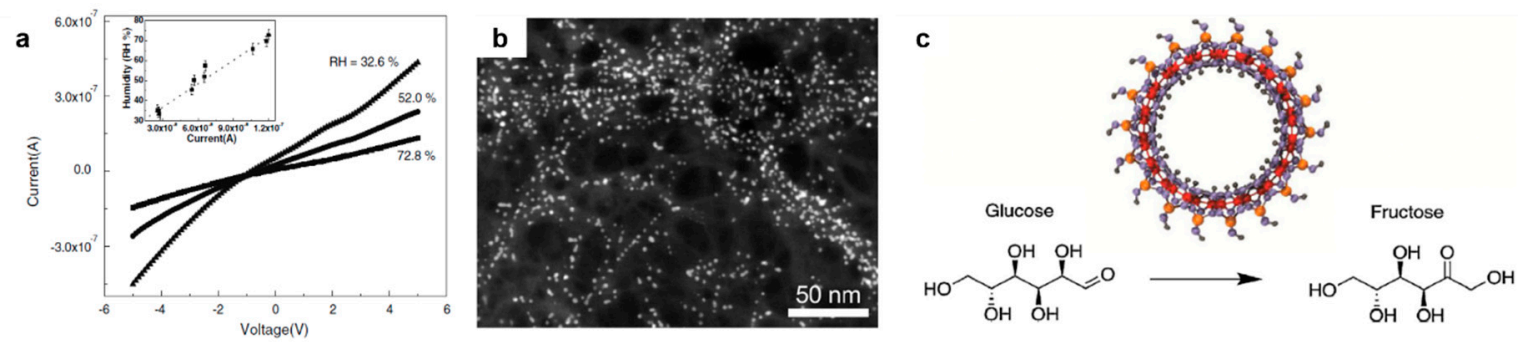

Figure 8. Examples of nanodevices and catalysis applications using imogolite nanotubes (a) I-V curves of an INT film measured in a FET device at different relative humilities for water sensoring. Adapted with permission from [165]. (b) Stabilization of modified gold nanoparticles on outer surface of INTs. Adapted with permissions from [167]. (c) Selective isomerization of glucose to fructose by INTs. Adapted with permissions from [78].

Indeed, imogolite nanotubes were suggested as a unique catalyst since 1983 [35], due to their defined porosity, regular internal and external surface and its ease of functionalization. However, 
this field remains less explored compared to the production of polymer/INT nanocomposites. Imamura et al. evidenced that $\mathrm{Cu}$-imogolite had higher activity in the decomposition of tert-butyl hydroperoxide than unloaded imogolite and $\mathrm{Cu}-\mathrm{SiO}_{2}$ materials [174]. In a similar manner, $\mathrm{Cu}^{2+}$-grafted $\mathrm{TiO}_{2} / \mathrm{INT}$ composites exhibited very efficient absorption and photodecomposition of acetaldehyde without being affected by the relative humidity, offering a wide range of uses in different environments [175]. Imogolite nanotubes and their derivatives have also been applied for hydroxylation of olefins [80], catalytic oxidation of aromatic hydrocarbon [176] or azo-dyes [106,177] and act as a tunable platform for the isomerization of glucose to fructose (Figure 8c) [78].

\section{Conclusions and Perspectives}

We have shown that it is now possible designing innovative imogolite nanostructures with hybrid interfaces in a predictive way. This represents an important prerequisite for future developments in nanomaterials and nanotechnologies. With their controlled morphology, tunable interfaces and unique colloidal properties, synthetic INTs appear as promising and flexible building blocks with multipurpose applications. Although the unique properties of imogolite nanotubes have been recognized for a long time [35], their combination for potential applications has been developed only recently. It is interesting to note, however, that most of the applications explored up to now, employ at least two of these properties (Figure 9).

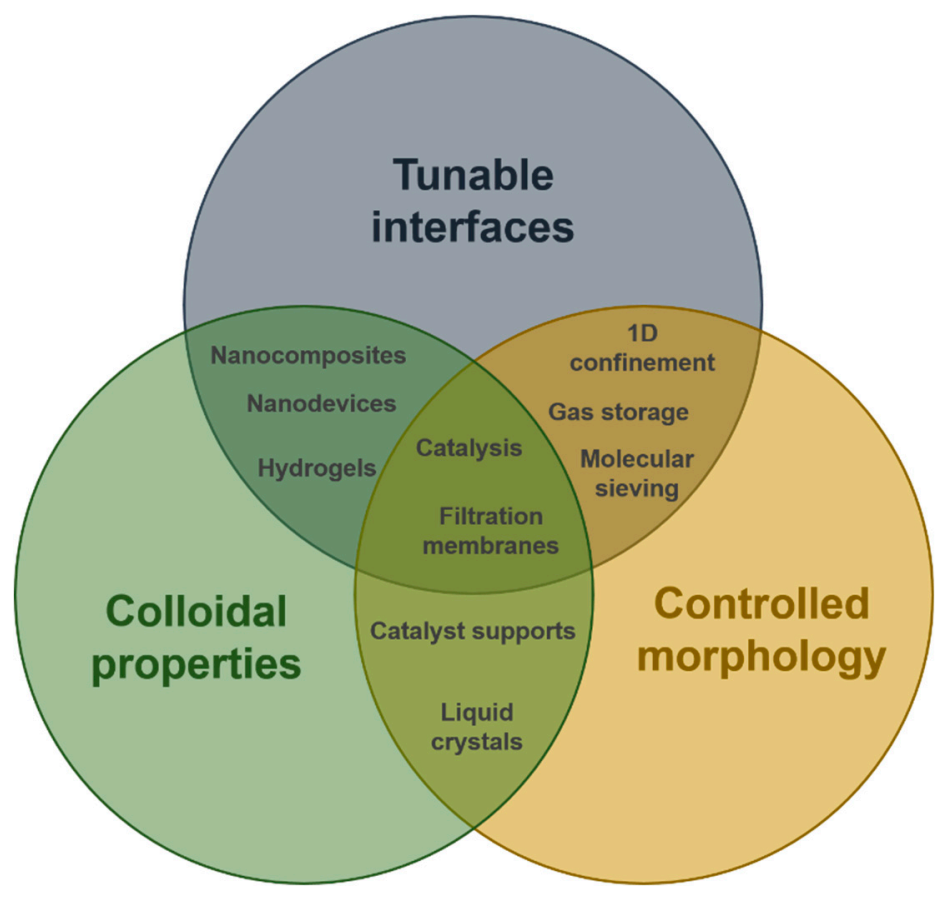

Figure 9. Schematic illustration of imogolite nanotubes properties (circles) and their combined uses for different applications.

This is likely related to a usage of INTs restricted only to their aluminosilicate form while Ge analogues just start to receive attention (Tables 2 and 3). This is particularly obvious in the case of hybrid imogolite/polymer nanocomposites, where the use of INTs with adjustable diameters by isomorphic substitution could open up new opportunities for molecular selectivity of confined species. As far as molecular confinement is concerned, INTs offer one of the rare possibilities to probe the confined dynamics of water in well-defined geometries and for different interactions with the interface, which will be relevant not only for fundamental physics but also in chemistry, geology or biology where water in nanopores of various natures is of prime importance $[178,179]$. However, a comprehensive understanding of the confinement phenomena themselves (structural and dynamical processes) is still 
lacking, possibly due to the difficulty and complexity in obtaining experimental details in perfectly controlled samples. This challenging task should be considered for future nanofluidic applications based on INTs.

Besides the possibility to synthesize either hydrophilic or hydrophobic INT structures, their growth mode by oriented attachment (OA) coupling [180] may also offer a unique path to control the morphology of the final nanotube. This feature could be employed to produce hybrid INTs with successive hydrophilic and hydrophobic sections and should be relevant for the development of innovative catalytic nanoreactors. Another attempt should be made by exploiting their ability to self-organize spontaneously in aqueous suspensions and their easy alignment in an electric field in order to drive nanotube organization in the resulting material. This could be the first step towards the elaboration of anisotropic nanocomposite materials with well-dispersed nanotube filler and may be used as artificial ion channel devices [181]. Moreover, potential photonic applications would be expected by doping INTs with dyes while controlling their spatial organization by applying external stimuli. Tissue engineering is another field [182], where INTs properties could be useful as scaffolds to support and promote the growth of new tissues. Some studies have been undertaken to investigate this possibility and paved the way for future research, in particular by using the full range of modifications offered by the imogolite structure $[159,183,184]$. Finally, it was recently suggested, on the basis of DFT calculations, that the permanent polarization of imogolite nanotubes could be used for polarization-enhanced photocatalysis $[185,186]$, an alternative to photoferroelectrics $[187,188]$. The promising use of polarized 1D nanotubes for coupling confinement and photocatalysis deserves to be explored experimentally in the near future.

Funding: This research received no external funding. The APC was funded by the Laboratoire de Physique des Solides.

Acknowledgments: The author thanks G. Monet, S. Rouzière, P. Launois and S. Lanone for helpful discussions.

Conflicts of Interest: The author declares no conflict of interest.

\section{References}

1. Iijima, S. Helical microtubules of graphitic carbon. Nature 1991, 354, 56-58. [CrossRef]

2. Iijima, S.; Ichihashi, T. Single-shell carbon nanotubes of 1-nm diameter. Nature 1993, 363, 603-605. [CrossRef]

3. Bethune, D.S.; Kiang, C.H.; De Vries, M.S.; Gorman, G.; Savoy, R.; Vazquez, J.; Beyers, R. Cobalt-catalysed growth of carbon nanotubes with single-atomic-layer walls. Nature 1993, 363, 605-607. [CrossRef]

4. Chopra, N.G.; Luyken, R.J.; Cherrey, K.; Crespi, V.H.; Cohen, M.L.; Louie, S.G.; Zettl, A. Boron nitride nanotubes. Science 1995, 269, 966-967. [CrossRef] [PubMed]

5. Tenne, R.; Margulis, L.; Genut, M.; Hodes, G. Polyhedral and cylindrical structures of tungsten disulphide. Nature 1992, 360, 444-446. [CrossRef]

6. Remškar, M. Inorganic nanotubes. Adv. Mater. 2004, 16, 1497-1504. [CrossRef]

7. Joussein, E.; Petit, S.; Churchman, J.; Theng, B.; Righi, D.; Delvaux, B. Halloysite clay minerals-A review. Clay Miner. 2005, 40, 383-426. [CrossRef]

8. $\mathrm{Hu}$, S.; Wang, X. Single-walled $\mathrm{MoO}_{3}$ nanotubes. J. Am. Chem. Soc. 2008, 130, 8126-8127. [CrossRef] [PubMed]

9. Ni, B.; Liu, H.; Wang, P.; He, J.; Wang, X. General synthesis of inorganic single-walled nanotubes. Nat. Commun. 2015, 6, 8756. [CrossRef] [PubMed]

10. Bradley, K.; Gabriel, J.-C.P.; Grüner, G. Flexible nanotube electronics. Nano Lett. 2003, 3, 1353-1355. [CrossRef]

11. Guo, S.; Meshot, E.R.; Kuykendall, T.; Cabrini, S.; Fornasiero, F. Nanofluidic transport through isolated carbon nanotube channels: Advances, controversies, and challenges. Adv. Mater. 2015, 27, 5726-5737. [CrossRef] [PubMed]

12. Geng, J.; Kim, K.; Zhang, J.; Escalada, A.; Tunuguntla, R.; Comolli, L.R.; Allen, F.I.; Shnyrova, A.V.; Cho, K.R.; Munoz, D. Stochastic transport through carbon nanotubes in lipid bilayers and live cell membranes. Nature 2014, 514, 612-615. [CrossRef] [PubMed] 
13. Siria, A.; Poncharal, P.; Biance, A.-L.; Fulcrand, R.; Blase, X.; Purcell, S.T.; Bocquet, L. Giant osmotic energy conversion measured in a single transmembrane boron nitride nanotube. Nature 2013, 494, 455-458. [CrossRef] [PubMed]

14. Park, H.G.; Jung, Y. Carbon nanofluidics of rapid water transport for energy applications. Chem. Soc. Rev. 2014, 43, 565-576. [CrossRef] [PubMed]

15. Serp, P.; Castillejos, E. Catalysis in carbon nanotubes. ChemCatChem 2010, 2, 41-47. [CrossRef]

16. Sanchez-Ballester, N.M.; Ramesh, G.V.; Tanabe, T.; Koudelkova, E.; Liu, J.; Shrestha, L.K.; Lvov, Y.; Hill, J.P.; Ariga, K.; Abe, H. Activated interiors of clay nanotubes for agglomeration-tolerant automotive exhaust remediation. J. Mater. Chem. A 2015, 3, 6614-6619. [CrossRef]

17. Lvov, Y.; Wang, W.; Zhang, L.; Fakhrullin, R. Halloysite clay nanotubes for loading and sustained release of functional compounds. Adv. Mater. 2016, 28, 1227-1250. [CrossRef] [PubMed]

18. Lazzara, G.; Cavallaro, G.; Panchal, A.; Fakhrullin, R.; Stavitskaya, A.; Vinokurov, V.; Lvov, Y. An assembly of organic-inorganic composites using halloysite clay nanotubes. Curr. Opin. Colloid Interface Sci. 2018, 35, 42-50. [CrossRef]

19. Cradwick, P.D.G.; Wada, K.; Russell, J.; Yoshinaga, N.; Masson, C.; Farmer, V. Imogolite, a Hydrated Aluminum Silicate of Tubular Structure. Nat. Phys. Sci. 1972, 240, 187-189. [CrossRef]

20. Parfitt, R.L. Allophane and imogolite: Role in soil biogeochemical processes. Clay Miner. 2009, 44, 135-155. [CrossRef]

21. Bishop, J.L.; Fairén, A.G.; Michalski, J.R.; Gago-Duport, L.; Baker, L.L.; Velbel, M.A.; Gross, C.; Rampe, E.B. Surface clay formation during short-term warmer and wetter conditions on a largely cold ancient Mars. Nat. Astron. 2018, 2, 206-213. [CrossRef]

22. Farmer, V.; Fraser, A.; Tait, J. Synthesis of Imogolite-Tubular Aluminum Silicate Polymer. J. Chem. Soc. Chem. Commun. 1977, 462-463. [CrossRef]

23. Konduri, S.; Mukherjee, S.; Nair, S. Strain energy minimum and vibrational properties of single-walled aluminosilicate nanotubes. Phys. Rev. B 2006, 74, 033401. [CrossRef]

24. Guimaraes, L.; Enyashin, A.N.; Frenzel, J.; Heine, T.; Duarte, H.A.; Seifert, G. Imogolite nanotubes: Stability, electronic, and mechanical properties. ACS Nano 2007, 1, 362-368. [CrossRef] [PubMed]

25. Teobaldi, G.; Beglitis, N.S.; Fisher, A.J.; Zerbetto, F.; Hofer, A.A. Hydroxyl vacancies in single-walled aluminosilicate and aluminogermanate nanotubes. J. Phys. Condens. Matter 2009, 21, 195301. [CrossRef] [PubMed]

26. Lourenco, M.P.; Guimaraes, L.; da Silva, M.C.; de Oliveira, C.; Heine, T.; Duarte, H.A. Nanotubes With Well-Defined Structure: Single- and Double-Walled Imogolites. J. Phys. Chem. C 2014, 118, 5945-5953. [CrossRef]

27. Poli, E.; Elliott, J.D.; Hine, N.D.M.; Mostofi, A.A.; Teobaldi, G. Large-scale density functional theory simulation of inorganic nanotubes: A case study on Imogolite nanotubes. Mater. Res. Innov. 2015, 19, S272-S282. [CrossRef]

28. Maillet, P.; Levard, C.; Spalla, O.; Masion, A.; Rose, J.; Thill, A. Growth kinetic of single and double-walled aluminogermanate imogolite-like nanotubes: An experimental and modeling approach. Phys. Chem. Chem. Phys. 2011, 13, 2682-2689. [CrossRef] [PubMed]

29. Yucelen, G.I.; Kang, D.-Y.; Schmidt-Krey, I.; Beckham, H.W.; Nair, S. A generalized kinetic model for the formation and growth of single-walled metal oxide nanotubes. Chem. Eng. Sci. 2013, 90, 200-212. [CrossRef]

30. Monet, G.; Amara, M.S.; Rouzière, S.; Paineau, E.; Chai, Z.; Elliott, J.D.; Poli, E.; Liu, L.-M.; Teobaldi, G.; Launois, P. Structural resolution of inorganic nanotubes with complex stoichiometry. Nat. Commun. 2018, 9, 2033. [CrossRef] [PubMed]

31. Hernandez, E.; Goze, C.; Bernier, P.; Rubio, A. Elastic properties of $C$ and $B_{x} C_{y} N_{z}$ composite nanotubes. Phys. Rev. Lett. 1998, 80, 4502. [CrossRef]

32. Seifert, G.; Terrones, H.; Terrones, M.; Jungnickel, G.; Frauenheim, T. Structure and electronic properties of $\mathrm{MoS}_{2}$ nanotubes. Phys. Rev. Lett. 2000, 85, 146. [CrossRef] [PubMed]

33. Pasbakhsh, P.; Churchman, G.J. Natural Mineral Nanotubes: Properties and Applications; CRC Press: Boca Raton, FL, USA, 2015; ISBN 1-4822-6225-8.

34. Yuan, P.; Thill, A.; Bergaya, F. Nanosized tubular Clay Minerals: Halloysite and Imogolite; Elsevier: Amsterdam, The Netherlands, 2016; Volume 7, ISBN 0-08-100292-0. 
35. Farmer, V.; Adams, M.; Fraser, A.; Palmieri, F. Synthetic Imogolite-Properties, Synthesis, and Possible Applications. Clay Miner. 1983, 18, 459-472. [CrossRef]

36. Barrett, S.; Budd, P.; Price, C. The Synthesis and Characterization of Imogolite. Eur. Polym. J. 1991, 27, 609-612. [CrossRef]

37. Marzan, L.L.; Philipse, A.P. Synthesis of platinum nanoparticles in aqueous host dispersions of inorganic (imogolite) rods. Colloids Surf. A Physicochem. Eng. Asp. 1994, 90, 95-109. [CrossRef]

38. Denaix, L.; Lamy, I.; Bottero, J.Y. Structure and affinity towards $\mathrm{Cd} 2+, \mathrm{Cu} 2+, \mathrm{Pb} 2+$ of synthetic colloidal amorphous aluminosilicates and their precursors. Colloids Surf. A Physicochem. Eng. Asp. 1999, 158, 315-325. [CrossRef]

39. Levard, C.; Masion, A.; Rose, J.; Doelsch, E.; Borschneck, D.; Dominici, C.; Ziarelli, F.; Bottero, J.-Y. Synthesis of Imogolite Fibers from Decimolar Concentration at Low Temperature and Ambient Pressure: A Promising Route for Inexpensive Nanotubes. J. Am. Chem. Soc. 2009, 131, 17080-17081. [CrossRef] [PubMed]

40. Chemmi, A.; Brendle, J.; Marichal, C.; Lebeau, B. Key Steps Influencing the Formation of Aluminosilicate Nanotubes by the Fluoride Route. Clays Clay Miner. 2015, 63, 132-143. [CrossRef]

41. Lam, C.H.; Yang, A.-C.; Chi, H.-Y.; Chan, K.-Y.; Hsieh, C.-C.; Kang, D.-Y. Microwave-Assisted Synthesis of Highly Monodispersed Single-Walled Alunminosilicate Nanotubes. ChemistrySelect 2016, 1, 6212-6216. [CrossRef]

42. Huling, J.C.; Bailey, J.K.; Smith, D.M.; Brinker, C.J. Imogolite as a material for fabrication of inorganic membranes. MRS Online Proc. Libr. Arch. 1992, 271, 511-516. [CrossRef]

43. Ackerman, W.; Smith, D.; Huling, J.; Kim, Y.; Bailey, J.; Brinker, C. Gas Vapor Adsorption in Imogolite-A Microporous Tubular Aluminosilicate. Langmuir 1993, 9, 1051-1057. [CrossRef]

44. Yucelen, G.I.; Kang, D.-Y.; Guerrero-Ferreira, R.C.; Wright, E.R.; Beckham, H.W.; Nair, S. Shaping Single-Walled Metal Oxide Nanotubes from Precursors of Controlled Curvature. Nano Lett. 2012, 12, 827-832. [CrossRef] [PubMed]

45. Arancibia-Miranda, N.; Escudey, M.; Ramirez, R.; Gonzalez, R.I.; van Duin, A.C.T.; Kiwi, M. Advancements in the Synthesis of Building Block Materials: Experimental Evidence and Modeled Interpretations of the Effect of Na and K on Imogolite Synthesis. J. Phys. Chem. C 2017, 121, 12658-12668. [CrossRef]

46. Inoue, K.; Huang, P. Influence of Citric-Acid on the Natural Formation of Imogolite. Nature 1984, 308, 58-60. [CrossRef]

47. Abidin, Z.; Matsue, N.; Henmi, T. Differential formation of allophane and imogolite: Experimental and molecular orbital study. J. Comput. Aided Mater. Des. 2007, 14, 5-18. [CrossRef]

48. Wada, S.; Wada, K. Effects of substitution of germanium for silicon in imogolite. Clays Clay Miner. 1982, 30, 123-128. [CrossRef]

49. Mukherjee, S.; Bartlow, V.A.; Nair, S. Phenomenology of the growth of single-walled aluminosilicate and aluminogermanate nanotubes of precise dimensions. Chem. Mater. 2005, 17, 4900-4909. [CrossRef]

50. Levard, C.; Rose, J.; Masion, A.; Doelsch, E.; Borschneck, D.; Olivi, L.; Dominici, C.; Grauby, O.; Woicik, J.C.; Bottero, J.-Y. Synthesis of large quantities of single-walled aluminogermanate nanotube. J. Am. Chem. Soc. 2008, 130, 5862-5863. [CrossRef] [PubMed]

51. Maillet, P.; Levard, C.; Larquet, E.; Mariet, C.; Spalla, O.; Menguy, N.; Masion, A.; Doelsch, E.; Rose, J.; Thill, A. Evidence of Double-Walled Al-Ge Imogolite-Like Nanotubes. A Cryo-TEM and SAXS Investigation. J. Am. Chem. Soc. 2010, 132, 1208-1209. [CrossRef] [PubMed]

52. Thill, A.; Maillet, P.; Guiose, B.; Spalla, O.; Belloni, L.; Chaurand, P.; Auffan, M.; Olivi, L.; Rose, J. Physico-chemical Control over the Single- or Double-Wall Structure of Aluminogermanate Imogolite-like Nanotubes. J. Am. Chem. Soc. 2012, 134, 3780-3786. [CrossRef] [PubMed]

53. Konduri, S.; Mukherjee, S.; Nair, S. Controlling nanotube dimensions: Correlation between composition, diameter, and internal energy of single-walled mixed oxide nanotubes. ACS Nano 2007, 1, 393-402. [CrossRef] [PubMed]

54. Thill, A.; Guiose, B.; Bacia-Verloop, M.; Geertsen, V.; Belloni, L. How the Diameter and Structure of $(\mathrm{OH})(3) \mathrm{Al}_{2} \mathrm{O}_{3} \mathrm{Si}_{\mathrm{x}} \mathrm{Ge}_{1-\mathrm{x}} \mathrm{OH}$ Imogolite Nanotubes Are Controlled by an Adhesion versus Curvature Cornpetition. J. Phys. Chem. C 2012, 116, 26841-26849. [CrossRef]

55. Amara, M.-S.; Paineau, E.; Bacia-Verloop, M.; Krapf, M.-E.M.; Davidson, P.; Belloni, L.; Levard, C.; Rose, J.; Launois, P.; Thill, A. Single-step formation of micron long $(\mathrm{OH})_{3} \mathrm{Al}_{2} \mathrm{O}_{3} \mathrm{Ge}(\mathrm{OH})$ imogolite-like nanotubes. Chem. Commun. 2013, 49, 11284-11286. [CrossRef] [PubMed] 
56. Gustafsson, J.P. Modelling competitive anion adsorption on oxide minerals and an allophane-containing soil. Eur. J. Soil Sci. 2001, 52, 639-653. [CrossRef]

57. Donkai, N.; Inagaki, H.; Kajiwara, K.; Urakawa, H.; Schmidt, M. Dilute-solution properties of imogolite. Makromol. Chem. Macromol. Chem. Phys. 1985, 186, 2623-2638. [CrossRef]

58. Karube, J. Hysteresis of the colloidal stability of imogolite. Clays Clay Miner. 1998, 46, 583-585. [CrossRef]

59. Philipse, A.P.; Wierenga, A.M. On the density and structure formation in gels and clusters of colloidal rods and fibers. Langmuir 1998, 14, 49-54. [CrossRef]

60. Paineau, E.; Krapf, M.-E.M.; Amara, M.-S.; Matskova, N.V.; Dozov, I.; Rouziere, S.; Thill, A.; Launois, P.; Davidson, P. A liquid-crystalline hexagonal columnar phase in highly-dilute suspensions of imogolite nanotubes. Nat. Commun. 2016, 7, 10271. [CrossRef] [PubMed]

61. Paineau, E.; Amara, M.S.; Monet, G.; Peyre, V.; Rouzière, S.; Launois, P. Effect of Ionic Strength on the Bundling of Metal Oxide Imogolite Nanotubes. J. Phys. Chem. C 2017, 121, 21740-21749. [CrossRef]

62. Amara, M.S.; Rouziere, S.; Paineau, E.; Bacia-Verloop, M.; Thill, A.; Launois, P. Hexagonalization of Aluminogermanate Imogolite Nanotubes Organized into Closed-Packed Bundles. J. Phys. Chem. C 2014, 118, 9299-9306. [CrossRef]

63. Karube, J.; Abe, Y. Water retention by colloidal allophane and imogolite with different charges. Clays Clay Miner. 1998, 46, 322-329. [CrossRef]

64. Ohashi, F.; Tomura, S.; Akaku, K.; Hayashi, S.; Wada, S.I. Characterization of synthetic imogolite nanotubes as gas storage. J. Mater. Sci. 2004, 39, 1799-1801. [CrossRef]

65. Creton, B.; Bougeard, D.; Smirnov, K.S.; Guilment, J.; Poncelet, O. Molecular dynamics study of hydrated imogolite-2. Structure and dynamics of confined water. Phys. Chem. Chem. Phys. 2008, 10, 4879-4888. [CrossRef] [PubMed]

66. Clark, C.; McBride, M. Cation and anion retention by natural and synthetic allophane and imogolite. Clays Clay Miner. 1984, 32, 291-299. [CrossRef]

67. Clark, C.; McBride, M. Chemisorption of $\mathrm{Cu}(\mathrm{II})$ and $\mathrm{Co}(\mathrm{II})$ on allophane and imogolite. Clays Clay Miner. 1984, 32, 300-310. [CrossRef]

68. Harsh, J.; Traina, S.; Boyle, J.; Yang, Y. Adsorption of cations on imogolite and their effect on surface-charge characteristics. Clays Clay Miner. 1992, 40, 700-706. [CrossRef]

69. Arai, Y.; McBeath, M.; Bargar, J.R.; Joye, J.; Davis, J.A. Uranyl adsorption and surface speciation at the imogolite-water interface: Self-consistent spectroscopic and surface complexation models. Geochim. Cosmochim. Acta 2006, 70, 2492-2509. [CrossRef]

70. Levard, C.; Doelsch, E.; Rose, J.; Masion, A.; Basile-Doelsch, I.; Proux, O.; Hazemann, J.-L.; Borschneck, D.; Bottero, J.-Y. Role of natural nanoparticles on the speciation of $\mathrm{Ni}$ in andosols of la Reunion. Geochim. Cosmochim. Acta 2009, 73, 4750-4760. [CrossRef]

71. Johnson, L.; Pinnavaia, T. Hydrolysis of (gamma-aminopropyl)triethoxysilane-silylated imogolite and formation of a silylated tubular silicate-layered nanocomposite. Langmuir 1991, 7, 2636-2641. [CrossRef]

72. Kang, D.-Y.; Brunelli, N.A.; Yucelen, G.I.; Venkatasubramanian, A.; Zang, J.; Leisen, J.; Hesketh, P.J.; Jones, C.W.; Nair, S. Direct synthesis of single-walled aminoaluminosilicate nanotubes with enhanced molecular adsorption selectivity. Nat. Commun. 2014, 5, 3342. [CrossRef] [PubMed]

73. Kang, D.-Y.; Zang, J.; Jones, C.W.; Nair, S. Single-Walled Aluminosilicate Nanotubes with Organic-Modified Interiors. J. Phys. Chem. C 2011, 115, 7676-7685. [CrossRef]

74. Boyer, M.; Paineau, E.; Bacia-Verloop, M.; Thill, A. Aqueous dispersion state of amphiphilic hybrid aluminosilicate nanotubes. Appl. Clay Sci. 2014, 96, 45-49. [CrossRef]

75. Bottero, I.; Bonelli, B.; Ashbrook, S.E.; Wright, P.A.; Zhou, W.; Tagliabue, M.; Armandi, M.; Garrone, E. Synthesis and characterization of hybrid organic/inorganic nanotubes of the imogolite type and their behaviour towards methane adsorption. Phys. Chem. Chem. Phys. 2011, 13, 744-750. [CrossRef] [PubMed]

76. Zanzottera, C.; Vicente, A.; Celasco, E.; Fernandez, C.; Garrone, E.; Bonelli, B. Physico-Chemical Properties of Imogolite Nanotubes Functionalized on Both External and Internal Surfaces. J. Phys. Chem. C 2012, 116, 7499-7506. [CrossRef]

77. Amara, M.S.; Paineau, E.; Rouziere, S.; Guiose, B.; Krapf, M.-E.M.; Tache, O.; Launois, P.; Thill, A. Hybrid, Tunable-Diameter, Metal Oxide Nanotubes for Trapping of Organic Molecules. Chem. Mater. 2015, 27, 1488-1494. [CrossRef] 
78. Olson, N.; Deshpande, N.; Gunduz, S.; Ozkan, U.S.; Brunelli, N.A. Utilizing imogolite nanotubes as a tunable catalytic material for the selective isomerization of glucose to fructose. Catal. Today 2018, in press. [CrossRef]

79. Johnson, L.; Pinnavaia, T. Silylation of a tubular aluminosilicate polymer (imogolite) by reaction with hydrolyzed (gamma-aminopropyl)triethoxysilane. Langmuir 1990, 6, 307-311. [CrossRef]

80. Qi, X.; Yoon, H.; Lee, S.-H.; Yoon, J.; Kim, S.-J. Surface-modified imogolite by 3-APS-OsO4 complex: Synthesis, characterization and its application in the dihydroxylation of olefins. J. Ind. Eng. Chem. 2008, 14, 136-141. [CrossRef]

81. Guerra, D.L.; Batista, A.C.; Viana, R.R.; Airoldi, C. Adsorption of rubidium on raw and MTZ- and MBI-imogolite hybrid surfaces: An evidence of the chelate effect. Desalination 2011, 275, 107-117. [CrossRef]

82. Guilment, J.; Martin, D.; Poncelet, O. Hybrid organic-inorganic materials designed to clean wash water in photographic processing: Genesis of a sot-gel industrial product the Kodak Water Saving Treatment System. In Organic/Inorganic Hybrid Materials-2002; Sanchez, C., Laine, R.M., Yang, S., Brinker, C.J., Eds.; Cambridge University Press: Cambridge, UK, 2002; Volume 726, pp. 217-222. ISBN 1-55899-662-1.

83. Yamamoto, K.; Otsuka, H.; Wada, S.; Takahara, A. Surface modification of aluminosilicate nanofiber "imogolite". Chem. Lett. 2001, 1162-1163. [CrossRef]

84. Yamamoto, K.; Otsuka, H.; Takahara, A.; Wada, S.I. Preparation of a novel (polymer/inorganic nanofiber) composite through surface modification of natural aluminosilicate nanofiber. J. Adhes. 2002, 78, 591-602. [CrossRef]

85. Park, S.; Lee, Y.; Kim, B.; Lee, J.; Jeong, Y.; Noh, J.; Takahara, A.; Sohn, D. Two-dimensional alignment of imogolite on a solid surface. Chem. Commun. 2007, 28, 2917-2919. [CrossRef] [PubMed]

86. Li, M.; Brant, J.A. Dispersing surface-modified imogolite nanotubes in polar and non-polar solvents. J. Nanopart. Res. 2018, 20, 19. [CrossRef]

87. Picot, P.; Tache, O.; Malloggi, F.; Coradin, T.; Thill, A. Behaviour of hybrid inside/out Janus nanotubes at an oil/water interface. A route to self-assembled nanofluidics? Faraday Discuss. 2016, 191, 391-406. [CrossRef] [PubMed]

88. Bac, B.H.; Song, Y.; Kim, M.H.; Lee, Y.-B.; Kang, I.M. Surface-modified aluminogermanate nanotube by OPA: Synthesis and characterization. Inorg. Chem. Commun. 2009, 12, 1045-1048. [CrossRef]

89. Ma, W.; Kim, J.; Otsuka, H.; Takahara, A. Surface Modification of Individual Imogolite Nanotubes with Alkyl Phosphate from an Aqueous Solution. Chem. Lett. 2011, 40, 159-161. [CrossRef]

90. Yamamoto, K.; Otsuka, H.; Wada, S.I.; Sohn, D.; Takahara, A. Preparation and properties of [poly(methyl methacrylate)/imogolite] hybrid via surface modification using phosphoric acid ester. Polymer 2005, 46, 12386-12392. [CrossRef]

91. Yah, W.O.; Irie, A.; Jiravanichanun, N.; Otsuka, H.; Takahara, A. Molecular Aggregation State and Electrical Properties of Terthiophenes/Imogolite Nanohybrids. Bull. Chem. Soc. Jpn. 2011, 84, 893-902. [CrossRef]

92. Ma, W.; Otsuka, H.; Takahara, A. Poly(methyl methacrylate) grafted imogolite nanotubes prepared through surface-initiated ARGET ATRP. Chem. Commun. 2011, 47, 5813-5815. [CrossRef] [PubMed]

93. Shikinaka, K.; Kaneda, K.; Mori, S.; Maki, T.; Masunaga, H.; Osada, Y.; Shigehara, K. Direct Evidence for Structural Transition Promoting Shear Thinning in Cylindrical Colloid Assemblies. Small 2014, 10, 1813-1820. [CrossRef] [PubMed]

94. Shikinaka, K.; Kikuchi, H.; Maki, T.; Shigehara, K.; Masunaga, H.; Sato, H. Chiral-Linkage-Induced Hierarchical Ordering of Colloidal Achiral Nanotubes in their Thixotropic Gel. Langmuir 2016, 32, 3665-3669. [CrossRef] [PubMed]

95. Jiravanichanun, N.; Yamamoto, K.; Irie, A.; Otsuka, H.; Takahara, A. Preparation of hybrid films of aluminosilicate nanofiber and conjugated polymer. Synth. Met. 2009, 159, 885-888. [CrossRef]

96. Miura, S.; Teramoto, N.; Shibata, M. Nanocomposites composed of poly(epsilon-caprolactone) and oligocaprolactone-modified imogolite utilizing biomimetic chelating method. J. Polym. Res. 2016, 23, 19. [CrossRef]

97. Shikinaka, K.; Abe, A.; Shigehara, K. Nanohybrid film consisted of hydrophobized imogolite and various aliphatic polyesters. Polymer 2015, 68, 279-283. [CrossRef]

98. Lee, Y.; Kim, B.; Yi, W.; Takahara, A.; Sohn, D. Conducting properties of polypyrrole coated imogolite. Bull. Korean Chem. Soc. 2006, 27, 1815-1818.

99. Chang, S.; Park, J.; Jang, J.; Lee, J.; Lee, J.; Yi, W. Effect of UV irradiation during synthesis of polypyrrole by a one-step deposition/polymerization process. J. Vacuum Sci. Technol. B 2007, 25, 670-673. [CrossRef] 
100. Lee, H.; Ryu, J.; Kim, D.; Joo, Y.; Lee, S.U.; Sohn, D. Preparation of an imogolite/poly(acrylic acid) hybrid gel. J. Colloid Interface Sci. 2013, 406, 165-171. [CrossRef] [PubMed]

101. Ryu, J.; Kim, H.; Kim, J.; Ko, J.; Sohn, D. Dynamic behavior of hybrid poly (acrylic acid) gel prepared by $\gamma$-ray irradiated imogolite. Colloids Surf. A Physicochem. Eng. Asp. 2017, 535, 166-174. [CrossRef]

102. Ookawa, M.; Inoue, Y.; Watanabe, M.; Suzuki, M.; Yamaguchi, T. Synthesis and characterization of Fe containing imogolite. Clay Sci. 2006, 12, 280-284.

103. Ookawa, M. Synthesis and Characterization of Fe-Imogolite as an Oxidation Catalyst. Clay Miner. Nat. Their Charact. Modif. Appl. 2013, 239-258. [CrossRef]

104. Shafia, E.; Esposito, S.; Manzoli, M.; Chiesa, M.; Tiberto, P.; Barrera, G.; Menard, G.; Allia, P.; Freyria, F.S.; Garrone, E.; et al. Al/Fe isomorphic substitution versus $\mathrm{Fe}_{2} \mathrm{O}_{3}$ clusters formation in Fe-doped aluminosilicate nanotubes (imogolite). J. Nanopart. Res. 2015, 17, 336. [CrossRef]

105. Shafia, E.; Esposito, S.; Armandi, M.; Manzoli, M.; Garrone, E.; Bonelli, B. Isomorphic substitution of aluminium by iron into single-walled alumino-silicate nanotubes: A physico-chemical insight into the structural and adsorption properties of Fe-doped imogolite. Microporous Mesoporous Mater. 2016, 224, 229-238. [CrossRef]

106. Bahadori, E.; Vaiano, V.; Esposito, S.; Armandi, M.; Sannino, D.; Bonelli, B. Photo-activated degradation of tartrazine by $\mathrm{H}_{2} \mathrm{O}_{2}$ as catalyzed by both bare and Fe-doped methyl-imogolite nanotubes. Catal. Today 2018, 304, 199-207. [CrossRef]

107. Avellan, A.; Levard, C.; Kumar, N.; Rose, J.; Olivi, L.; Thill, A.; Chaurand, P.; Borschneck, D.; Masion, A. Structural incorporation of iron into Ge-imogolite nanotubes: A promising step for innovative nanomaterials. RSC Adv. 2014, 4, 49827-49830. [CrossRef]

108. Neouze, M.-A.; Schubert, U. Surface modification and functionalization of metal and metal oxide nanoparticles by organic ligands. Monatshefte Chem. Chem. Mon. 2008, 139, 183-195. [CrossRef]

109. Alvarez-Ramirez, F. First Principles Studies of Fe-Containing Aluminosilicate and Aluminogermanate Nanotubes. J. Chem. Theory Comput. 2009, 5, 3224-3231. [CrossRef] [PubMed]

110. Alvarez-Ramirez, F. Theoretical Study of $(\mathrm{OH})(3) \mathrm{N}_{2} \mathrm{O}_{3} \mathrm{MOH}, \mathrm{M}=\mathrm{C}, \mathrm{Si}, \mathrm{Ge}, \mathrm{Sn}$ and $\mathrm{N}=\mathrm{Al}, \mathrm{Ga}$, In, with Imogolite-Like Structure. J. Comput. Theor. Nanosci. 2009, 6, 1120-1124. [CrossRef]

111. Guimaraes, L.; Pinto, Y.N.; Lourenco, M.P.; Duarte, H.A. Imogolite-like nanotubes: Structure, stability, electronic and mechanical properties of the phosphorous and arsenic derivatives. Phys. Chem. Chem. Phys. 2013, 15, 4303-4309. [CrossRef] [PubMed]

112. Bonelli, B.; Bottero, I.; Ballarini, N.; Passeri, S.; Cavani, F.; Garrone, E. IR spectroscopic and catalytic characterization of the acidity of imogolite-based systems. J. Catal. 2009, 264, 15-30. [CrossRef]

113. Zanzottera, C.; Armandi, M.; Esposito, S.; Garrone, E.; Bonelli, B. $\mathrm{CO}_{2}$ Adsorption on Aluminosilicate Single-Walled Nanotubes of Imogolite Type. J. Phys. Chem. C 2012, 116, 20417-20425. [CrossRef]

114. Wilson, M.A.; Lee, G.S.H.; Taylor, R.C. Benzene displacement on imogolite. Clays Clay Miner. 2002, 50, 348-351. [CrossRef]

115. Bonelli, B.; Zanzottera, C.; Armandi, M.; Esposito, S.; Garrone, E. IR spectroscopic study of the acidic properties of alumino-silicate single-walled nanotubes of the imogolite type. Catal. Today 2013, 218, 3-9. [CrossRef]

116. Bonelli, B.; Armandi, M.; Garrone, E. Surface properties of alumino-silicate single-walled nanotubes of the imogolite type. Phys. Chem. Chem. Phys. 2013, 15, 13381-13390. [CrossRef] [PubMed]

117. Konduri, S.; Tong, H.M.; Chempath, S.; Nair, S. Water in single-walled aluminosilicate nanotubes: Diffusion and adsorption properties. J. Phys. Chem. C 2008, 112, 15367-15374. [CrossRef]

118. Scalfi, L.; Fraux, G.; Boutin, A.; Coudert, F.-X. Structure and Dynamics of Water Confined in Imogolite Nanotubes. Langmuir 2018, 34, 6748-6756. [CrossRef] [PubMed]

119. Holt, J.K.; Park, H.G.; Wang, Y.; Stadermann, M.; Artyukhin, A.B.; Grigoropoulos, C.P.; Noy, A.; Bakajin, O. Fast mass transport through sub-2-nanometer carbon nanotubes. Science 2006, 312, 1034-1037. [CrossRef] [PubMed]

120. Falk, K.; Sedlmeier, F.; Joly, L.; Netz, R.R.; Bocquet, L. Molecular origin of fast water transport in carbon nanotube membranes: Superlubricity versus curvature dependent friction. Nano Lett. 2010, 10, 4067-4073. [CrossRef] [PubMed]

121. Paineau, E.; Albouy, P.-A.; Rouziere, S.; Orecchini, A.; Rols, S.; Launois, P. X-ray Scattering Determination of the Structure of Water during Carbon Nanotube Filling. Nano Lett. 2013, 13, 1751-1756. [CrossRef] [PubMed] 
122. Bernardina, S.D.; Paineau, E.; Brubach, J.-B.; Judeinstein, P.; Rouziere, S.; Launois, P.; Roy, P. Water in Carbon Nanotubes: The Peculiar Hydrogen Bond Network Revealed by Infrared Spectroscopy. J. Am. Chem. Soc. 2016, 138, 10437-10443. [CrossRef] [PubMed]

123. Liao, Y.; Picot, P.; Lainé, M.; Brubach, J.-B.; Roy, P.; Thill, A.; Le Caër, S. Tuning the properties of confined water in standard andhybrid nanotubes: An infrared spectroscopic study. Nano Res. 2018, 11, 4759-4773. [CrossRef]

124. Zang, J.; Chempath, S.; Konduri, S.; Nair, S.; Sholl, D.S. Flexibility of Ordered Surface Hydroxyls Influences the Adsorption of Molecules in Single-Walled Aluminosilicate Nanotubes. J. Phys. Chem. Lett. 2010, 1, 1235-1240. [CrossRef]

125. Kojima, Y.; Usuki, A.; Kawasumi, M.; Okada, A.; Fukushima, Y.; Kurauchi, T.; Kamigaito, O. Mechanical properties of nylon 6-clay hybrid. J. Mater. Res. 1993, 8, 1185-1189. [CrossRef]

126. Ray, S.S.; Okamoto, M. Polymer/layered silicate nanocomposites: A review from preparation to processing. Prog. Polym. Sci. 2003, 28, 1539-1641.

127. Bitinis, N.; Hernández, M.; Verdejo, R.; Kenny, J.M.; Lopez-Manchado, M.A. Recent advances in clay/polymer nanocomposites. Adv. Mater. 2011, 23, 5229-5236. [CrossRef] [PubMed]

128. Yamamoto, K.; Otsuka, H.; Wada, S.I.; Sohn, D.; Takahara, A. Transparent polymer nanohybrid prepared by in situ synthesis of aluminosilicate nanofibers in poly(vinyl alcohol) solution. Soft Matter 2005, 1, 372-377. [CrossRef]

129. Hoshino, H.; Ito, T.; Donkai, N.; Urakawa, H.; Kajiwara, K. Lyotropic mesophase formation in PVA/imogolite mixture. Polym. Bull. 1992, 29, 453-460. [CrossRef]

130. Choi, J.H.; Cho, Y.W.; Ha, W.S.; Lyoo, W.S.; Lee, C.J.; Ji, B.C.; Han, S.S.; Yoon, W.S. Preparation and characterization of syndiotacticity-rich ultra-high molecular weight poly(vinyl alcohol) imogolite blend film. Polym. Int. 1998, 47, 237-242. [CrossRef]

131. Yang, A.-C.; Li, Y.-S.; Lam, C.H.; Chi, H.-Y.; Cheng, I.-C.; Kang, D.-Y. Solution-processed ultra-low-k thin films comprising single-walled aluminosilicate nanotubes. Nanoscale 2016, 8, 17427-17432. [CrossRef] [PubMed]

132. Su, C.-Y.; Yang, A.-C.; Jiang, J.-S.; Yang, Z.-H.; Huang, Y.-S.; Kang, D.-Y.; Hua, C.-C. Properties of Single-Walled Aluminosilicate Nanotube/Poly (vinyl alcohol) Aqueous Dispersions. J. Phys. Chem. B 2018, 122, 380-391. [CrossRef] [PubMed]

133. Kang, D.-Y.; Tong, H.M.; Zang, J.; Choudhury, R.P.; Sholl, D.S.; Beckham, H.W.; Jones, C.W.; Nair, S. Single-Walled Aluminosilicate Nanotube/Poly(vinyl alcohol) Nanocomposite Membranes. ACS Appl. Mater. Interfaces 2012, 4, 965-976. [CrossRef] [PubMed]

134. Barona, G.N.B.; Choi, M.; Jung, B. High permeate flux of PVA/PSf thin film composite nanofiltration membrane with aluminosilicate single-walled nanotubes. J. Colloid Interface Sci. 2012, 386, 189-197. [CrossRef] [PubMed]

135. Kang, D.-Y.; Lydon, M.E.; Yucelen, G.I.; Jones, C.W.; Nair, S. Solution-Processed Ultrathin Aluminosilicate Nanotube-Poly(vinyl alcohol) Composite Membranes with Partial Alignment of Nanotubes. ChemNanoMat 2015, 1, 102-108. [CrossRef]

136. Ryu, J.; Ko, J.; Lee, H.; Shin, T.-G.; Sohn, D. Structural Response of Imogolite-Poly(acrylic acid) Hydrogel under Deformation. Macromolecules 2016, 49, 1873-1881. [CrossRef]

137. Shikinaka, K.; Yokoi, T.; Koizumi-Fujii, Y.; Shimotsuya, M.; Shigehara, K. Robust imogolite hydrogels with tunable physical properties. RSC Adv. 2015, 5, 46493-46500. [CrossRef]

138. Ma, W.; Otsuka, H.; Takahara, A. Preparation and properties of PVC/PMMA-g-imogolite nanohybrid via surface-initiated radical polymerization. Polymer 2011, 52, 5543-5550. [CrossRef]

139. Kuroda, Y.; Tamakoshi, M.; Murakami, J.; Kuroda, K. Fabrication of hierarchically ordered porous films composed of imogolite via colloidal templating. J. Ceram. Soc. Jpn. 2007, 115, 233-236. [CrossRef]

140. Kuroda, Y.; Kuroda, K. Layer-by-layer assembly of imogolite nanotubes and polyelectrolytes into core-shell particles and their conversion to hierarchically porous spheres. Sci. Technol. Adv. Mater. 2008, 9, 025018. [CrossRef] [PubMed]

141. Kuroda, Y.; Kuroda, K. Formation of Hierarchically Porous Hollow Spheres Composed of Dehydroxylated Imogolite and Carbonaceous Materials. Bull. Chem. Soc. Jpn. 2011, 84, 49-51. [CrossRef] 
142. Kuroda, Y.; Kuroda, K. Expansion of Intertubular Mesopores of Imogolite Nanotubes by Thermal Decomposition of an Imogolite-Poly(sodium 4-styrenesulfonate) Composite. Chem. Lett. 2011, 40, 46-48. [CrossRef]

143. Shikinaka, K.; Koizumi, Y.; Osada, Y.; Shigehara, K. Reinforcement of hydrogel by addition of fiber-like nanofiller. Polym. Adv. Technol. 2011, 22, 1212-1215. [CrossRef]

144. Shikinaka, K.; Koizumi, Y.; Kaneda, K.; Osada, Y.; Masunaga, H.; Shigehara, K. Strain-induced reversible isotropic-anisotropic structural transition of imogolite hydrogels. Polymer 2013, 54, 2489-2492. [CrossRef]

145. Barona, G.N.B.; Lim, J.; Choi, M.; Jung, B. Interfacial polymerization of polyamide-aluminosilicate SWNT nanocomposite membranes for reverse osmosis. Desalination 2013, 325, 138-147. [CrossRef]

146. Pan, Y.-H.; Zhao, Q.-Y.; Gu, L.; Wu, Q.-Y. Thin film nanocomposite membranes based on imologite nanotubes blended substrates for forward osmosis desalination. Desalination 2017, 421, 160-168. [CrossRef]

147. Li, M.; Brant, J.A. Synthesis of Polyamide Thin-Film Nanocomposite Membranes Using Surface Modified Imogolite Nanotubes. J. Membr. Sci. 2018, 563, 664-675. [CrossRef]

148. Shikinaka, K. Design of stimuli-responsive materials consisting of the rigid cylindrical inorganic polymer "imogolite". Polym. J. 2016, 48, 689-696. [CrossRef]

149. Shikinaka, K.; Taki, N.; Kaneda, K.; Tominaga, Y. Quasi-solid electrolyte: A thixotropic gel of imogolite and an ionic liquid. Chem. Commun. 2017, 53, 613-616. [CrossRef] [PubMed]

150. Hoshino, H.; Yamana, M.; Donkai, N.; Sinigersky, V.; Kajiwara, K.; Miyamoto, T.; Inagaki, H. Lyotropic mesophase formations of HPC/imogolite mixture. Polym. Bull. 1992, 28, 607-614. [CrossRef]

151. Yah, W.O.; Irie, A.; Otsuka, H.; Sasaki, S.; Yagi, N.; Sato, M.; Koganezawa, T.; Takahara, A. Molecular Aggregation States of Imogolite/P3HT Nanofiber Hybrid. J. Phys. Conf. Ser. 2011, 272, 012021. [CrossRef]

152. Levard, C.; Thill, A.; Avellan, A.; Mauroy, C.; Vidal, V.; Campos, A.P.C.; Masion, A.; Rose, J. Alignment of Ge-imogolite nanotubes in isomalt with tunable inter-tube distances. RSC Adv. 2017, 7, 21323-21327. [CrossRef]

153. Kato, K.; Inukai, K.; Fujikura, K.; Kasuga, T. Effective encapsulation of laccase in an aluminium silicate nanotube hydrogel. New J. Chem. 2014, 38, 3591-3599. [CrossRef]

154. Inoue, N.; Otsuka, H.; Wada, S.I.; Takahara, A. (Inorganic nanofiber/enzyme) hybrid hydrogel: Preparation, characterization, and enzymatic activity of imogolite/pepsin conjugate. Chem. Lett. 2006, 35, 194-195. [CrossRef]

155. Teramoto, N.; Hayashi, A.; Yamanaka, K.; Sakiyama, A.; Nakano, A.; Shibata, M. Preparation and Mechanical Properties of Photo-Crosslinked Fish Gelatin/Imogolite Nanofiber Composite Hydrogel. Materials 2012, 5 , 2573-2585. [CrossRef]

156. Jiravanichanun, N.; Yamamoto, K.; Kato, K.; Kim, J.; Horiuchi, S.; Yah, W.-O.; Otsuka, H.; Takahara, A. Preparation and Characterization of Imogolite/DNA Hybrid Hydrogels. Biomacromolecules 2012, 13, $276-281$. [CrossRef] [PubMed]

157. Park, K.-L.; Ma, W.; Higaki, Y.; Takahara, A. Design and characterization of hybrid hydrogels composed of imogolite fibrous nanotubular clay and hyaluronic acid. Polymer 2016, 100, 238-243. [CrossRef]

158. Bonini, M.; Gabbani, A.; Del Buffa, S.; Ridi, F.; Baglioni, P.; Bordes, R.; Holmberg, K. Adsorption of Amino Acids and Glutamic Acid-Based Surfactants on Imogolite Clays. Langmuir 2017, 33, 2411-2419. [CrossRef] [PubMed]

159. Gelli, R.; Del Buffa, S.; Tempesti, P.; Bonini, M.; Ridi, F.; Baglioni, P. Enhanced formation of hydroxyapatites in gelatin/imogolite macroporous hydrogels. J. Colloid Interface Sci. 2018, 511, 145-154. [CrossRef] [PubMed]

160. Mauroy, C.; Levard, C.; Moreau, C.; Vidal, V.; Rose, J.; Cathala, B. Elaboration of Cellulose Nanocrystal/ Ge-Imogolite Nanotube Multilayered Thin Films. Langmuir 2018, 34, 3386-3394. [CrossRef] [PubMed]

161. Liou, K.-H.; Kang, D.-Y.; Lin, L.-C. Investigating the Potential of Single-Walled Aluminosilicate Nanotubes in Water Desalination. ChemPhysChem 2017, 18, 179-183. [CrossRef] [PubMed]

162. Fornasiero, F.; Park, H.G.; Holt, J.K.; Stadermann, M.; Grigoropoulos, C.P.; Noy, A.; Bakajin, O. Ion exclusion by sub-2-nm carbon nanotube pores. Proc. Natl. Acad. Sci. USA 2008, 105, 17250-17255. [CrossRef] [PubMed]

163. Kajiwara, K.; Donkai, N.; Hiragi, Y.; Inagaki, H. Lyotropic mesophase of imogolite, 1. Effect of polydispersity on phase-diagram. Makromol. Chem. Macromol. Chem. Phys. 1986, 187, 2883-2893. [CrossRef]

164. Onsager, L. The effects of shape on the interaction of colloidal particles. Ann. N. Y. Acad. Sci. 1949, 51, 627-659. [CrossRef] 
165. Oh, J.; Chang, S.; Jang, J.; Roh, S.; Park, J.; Lee, J.; Sohn, D.; Yi, W.; Jung, Y.; Kim, S.-J. Imogolite as an electron emitter and a water sensor. J. Mater. Sci. Mater. Electron. 2007, 18, 893-897. [CrossRef]

166. Castro, C.; Arancibia-Miranda, N.; Acuna-Rougier, C.; Escudey, M.; Tasca, F. Spectroscopic and Electrochemical Studies of Imogolite and Fe-Modified Imogolite Nanotubes. Nanomaterials 2016, 6, 28. [CrossRef] [PubMed]

167. Kuroda, Y.; Fukumoto, K.; Kuroda, K. Uniform and high dispersion of gold nanoparticles on imogolite nanotubes and assembly into morphologically controlled materials. Appl. Clay Sci. 2012, 55, 10-17. [CrossRef]

168. Liz-Marzán, L.; Philipse, A. Stable hydrosols of metallic and bimetallic nanoparticles immobilized on imogolite fibers. J. Phys. Chem. 1995, 99, 15120-15128. [CrossRef]

169. Yamada, H.; Michalik, J.; Sadlo, J.; Perlinska, J.; Takenouchi, S.; Shimomura, S.; Uchida, Y. Electron spin resonance studies on silver atoms in imogolite fibers. Appl. Clay Sci. 2001, 19, 173-178. [CrossRef]

170. Arancibia-Miranda, N.; Escudey, M.; Pizarro, C.; Denardin, J.C.; Teresa Garcia-Gonzalez, M.; Fabris, J.D.; Charlet, L. Preparation and characterization of a single-walled aluminosilicate nanotube-iron oxide composite: Its applications to removal of aqueous arsenate. Mater. Res. Bull. 2014, 51, 145-152. [CrossRef]

171. Lerat, Y.J.; Poncelet, O.J. Dressing and Antiseptic Agent Containing Silver. Patent US7323614B2, 19 January 2008.

172. Geraldo, D.A.; Arancibia-Miranda, N.; Villagra, N.A.; Mora, G.C.; Arratia-Perez, R. Synthesis of CdTe QDs/single-walled aluminosilicate nanotubes hybrid compound and their antimicrobial activity on bacteria. J. Nanopart. Res. 2012, 14, 1286. [CrossRef]

173. Yucelen, G.I.; Connell, R.E.; Terbush, J.R.; Westenberg, D.J.; Dogan, F. Synthesis and immobilization of silver nanoparticles on aluminosilicate nanotubes and their antibacterial properties. Appl. Nanosci. 2016, 6, 607-614. [CrossRef]

174. Imamura, S.; Kokubu, T.; Yamashita, T.; Okamoto, Y.; Kajiwara, K.; Kanai, H. Shape-selective copper-loaded Imogolite catalyst. J. Catal. 1996, 160, 137-139. [CrossRef]

175. Katsumata, K.; Hou, X.; Sakai, M.; Nakajima, A.; Fujishima, A.; Matsushita, N.; MacKenzie, K.J.D.; Okada, K. Visible-light-driven photodegradation of acetaldehyde gas catalyzed by aluminosilicate nanotubes and $\mathrm{Cu}(\mathrm{II})$-grafted $\mathrm{TiO}_{2}$ composites. Appl. Catal. B Environ. 2013, 138, 243-252. [CrossRef]

176. Ookawa, M.; Takata, Y.; Suzuki, M.; Inukai, K.; Maekawa, T.; Yamaguchi, T. Oxidation of aromatic hydrocarbons with $\mathrm{H}(2) \mathrm{O}(2)$ catalyzed by a nano-scale tubular aluminosilicate, Fe-containing imogolite. Res. Chem. Intermed. 2008, 34, 679-685. [CrossRef]

177. Shafia, E.; Esposito, S.; Armandi, M.; Bahadori, E.; Garrone, E.; Bonelli, B. Reactivity of bare and Fe-doped alumino-silicate nanotubes (imogolite) with $\mathrm{H}_{2} \mathrm{O}_{2}$ and the azo-dye Acid Orange 7. Catal. Today 2016, 277, 89-96. [CrossRef]

178. Sui, H.; Han, B.-G.; Lee, J.K.; Walian, P.; Jap, B.K. Structural basis of water-specific transport through the AQP1 water channel. Nature 2001, 414, 872-878. [CrossRef] [PubMed]

179. Cohen-Tanugi, D.; Grossman, J.C. Water desalination across nanoporous graphene. Nano Lett. 2012, 12, 3602-3608. [CrossRef] [PubMed]

180. De Yoreo, J.J.; Gilbert, P.U.; Sommerdijk, N.A.; Penn, R.L.; Whitelam, S.; Joester, D.; Zhang, H.; Rimer, J.D.; Navrotsky, A.; Banfield, J.F. Crystallization by particle attachment in synthetic, biogenic, and geologic environments. Science 2015, 349, aaa6760. [CrossRef] [PubMed]

181. Tunuguntla, R.H.; Henley, R.Y.; Yao, Y.-C.; Pham, T.A.; Wanunu, M.; Noy, A. Enhanced water permeability and tunable ion selectivity in subnanometer carbon nanotube porins. Science 2017, 357, 792-796. [CrossRef] [PubMed]

182. O'brien, F.J. Biomaterials \& scaffolds for tissue engineering. Mater. Today 2011, 14, 88-95.

183. Ishikawa, K.; Abe, S.; Yawaka, Y.; Suzuki, M.; Watari, F. Osteoblastic cellular responses to aluminosilicate nanotubes, imogolite using Saos-2 and MC3T3-E1 cells. J. Ceram. Soc. Jpn. 2010, 118, 516-520. [CrossRef]

184. Ishikawa, K.; Akasaka, T.; Abe, S.; Yawaka, Y.; Suzuki, M.; Watari, F. Application of imogolite, almino-silicate nanotube, as scaffold for the mineralization of osteoblasts. Bioceram. Dev. Appl. 2011, 1, 1-3. [CrossRef]

185. Poli, E.; Elliott, J.D.; Ratcliff, L.E.; Andrinopoulos, L.; Dziedzic, J.; Hine, N.D.M.; Mostofi, A.A.; Skylaris, C.-K.; Haynes, P.D.; Teobaldi, G. The potential of imogolite nanotubes as (co-)photocatalysts: A linear-scaling density functional theory study. J. Phys. Condens. Matter 2016, 28, 074003. [CrossRef] [PubMed] 
186. Elliott, J.D.; Poli, E.; Scivetti, I.; Ratcliff, L.E.; Andrinopoulos, L.; Dziedzic, J.; Hine, N.D.M.; Mostofi, A.A.; Skylaris, C.-K.; Haynes, P.D.; et al. Chemically Selective Alternatives to Photoferroelectrics for PolarizationEnhanced Photocatalysis: The Untapped Potential of Hybrid Inorganic Nanotubes. Adv. Sci. 2017, 4, 1600153. [CrossRef] [PubMed]

187. Bhavanasi, V.; Kusuma, D.Y.; Lee, P.S. Polarization Orientation, Piezoelectricity, and Energy Harvesting Performance of Ferroelectric PVDF-TrFE Nanotubes Synthesized by Nanoconfinement. Adv. Energy Mater. 2014, 4, 1400723. [CrossRef]

188. Su, R.; Shen, Y.; Li, L.; Zhang, D.; Yang, G.; Gao, C.; Yang, Y. Silver-Modified Nanosized Ferroelectrics as a Novel Photocatalyst. Small 2015, 11, 202-207. [CrossRef] [PubMed]

2018 by the author. Licensee MDPI, Basel, Switzerland. This article is an open access article distributed under the terms and conditions of the Creative Commons Attribution (CC BY) license (http://creativecommons.org/licenses/by/4.0/). 